
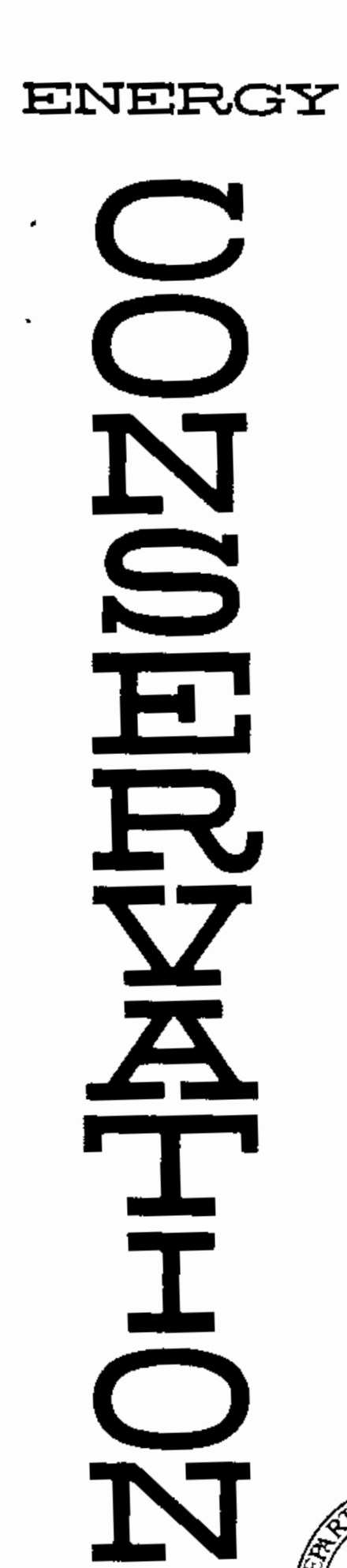

\title{
ECONOMIC AND ENERGY AUDIT OF TEXTILE FOAM PROCESSING
}

By

Raymond Machacek

June 1983

Work Performed Under Contract No. AC06-76RL01830

Arthur D. Little, Inc.

Cambridge, Massachusetts

\section{U. S. DEPARTMENT OF ENERGY}




\title{
DISCLAIMER
}

\begin{abstract}
This renort was prepared as atl accourst of work sponsored by an arency of the linited Slates Government. Neither the linited States Government nor any agency thereot, nur any of thet employees, makes any warranty express or implied, or ussumes any legal liability or responsi. bility for lire accuracy, completeness, ur usefultress of any infoimation, apparalus, proxuts, ai proxess disctosed, or represents that its us: would not infringe privatelv owned tighis. Rej: ence herein to any specific commercial product, process. or serice by trade name. traotemas: manalacturer, or ofletwise doen not aecessarly eorstitute or imply its endorsement, recory:

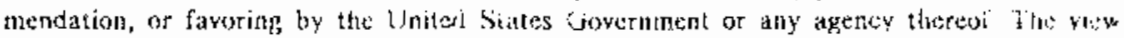

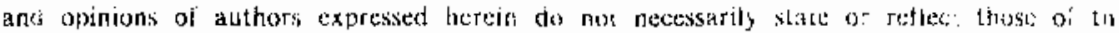

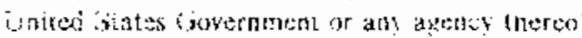

This report has been reproduced directe trom the best availabie copy.

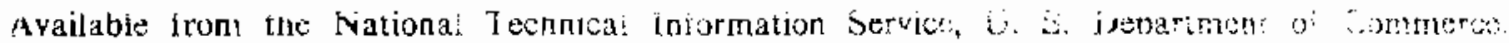

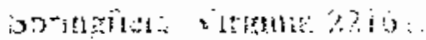

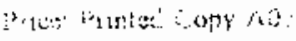

$$
\begin{aligned}
& \text { im dorolion: Ali }
\end{aligned}
$$

Codes are used for pricing all nublications. The code is determined by the number of pages in the publication. Information pertaining to the pricing codes can be found in the current issues of the following publications, which are generally available in most libraries: Energy Research Abstracts (ERA); Government Reports Announcements and Index (GRA and 1); Scientific and Technical Abstract Reports (STAR); and publication NTIS-PR-350 available from NTIS ai the abow: adares. 


\title{
ECONOMIC AND ENERGY AUDIT OF
} TEXTILE FOAM PROCESSING

\author{
Ray Mahacek \\ Arthur D. Little, Inc.
}

June 1983

Prepared for the U.S. Department of Energy under contract OE-ACO6-76RLO 1830

Pacific Northwest Laboratory Richland, Washington 99352 
List of Figures

List of Tables

1.0 EXECUTIVE SUMMARY

1.1 BACKGROUND

1.2 FINDINGS

2.0 OBJECTIVE AND GOALS 3

3.0 SCOPE AND APPROACH 5

3.1 EVALUATION OF EXISTING PROCESSES

3.2 REVIEW AND EVALUATION OF FOAM

FINISHING

3.3 REVIEW AND EVALUATION OF DATA REQUIREMENTS

3.4 REVIEW OF DATA SAMPLING PROCEDURE AND DATA COLLECTION

4.0 FINDINGS

4.1 COMPARISON OF PROCESS ENERGY USE

4.2 COMPARISON OF ECONOMICS 20

5.0 CONCLUSIONS AND RECOMMENDATIONS 33

APPENDIX A - HEAT AND WATER BALANCES TO CHECK ACCURACY OF MONITORING EQUIPMENT A.1

APPENDIX B - SUMMARIZED DATA B-1

APPENDIX C - RESULTS OF COMPUTERIZED PAYBACK- 


\section{LIST OF FIGURES}

Figure No. $\quad$ Page

3.1 Schematic - Finishing Process for Wet Pickup of Chemicals Tubular Knits and Broad-Woven Fabrics

3.2 Schematic - Carpet Dyeing

Conventional Beck Process

3.3 Schematic - Wet Continuous Dyeing and Drying of Carpets

8

3.4 Schematic - Finishing Process for Foam Pickup of Chemicals

Tubular Knits and Broad-Woven Fabrics

3.5 Schematic - Continuous Foam Dyeing and Air Drying

of Carpets 


\section{LIST OF TABLES}

Table No.

$\begin{array}{lll}3.1 & \text { Foam Finishing Test Results } & 13\end{array}$

3.2 Wet Continuous Dyeing of Carpets 14

4.1 Moisture Pickup Wet vs Foam Finishing 15

4.2 Energy Used to Finish Fabrics 16

$\begin{array}{lll}4.3 & \text { Dryer Efficiencies } & 17\end{array}$

4.4 Annual Energy Consumption for Finishing Tubular Knits $\quad 18$

4.5 Annual Energy Consumption for Finishing Broad Wovens 19

4.6 Annual Energy Consumption for Beck Dyeing of Carpets $\begin{array}{ll}\text { Compared with Foam Dyeing } & 19\end{array}$

4.7 Annual Energy Consumption for Wet Continuous Dyeing of Carpets Compared with Foam Dyeing 20

4.8 Operating Costs of Finishing Operations 20

4.9 Tubular Knits - Conventiona! Finishing 22

4.10 Tubular Knits - Foam Finishing 23

4.11 Broad Wovens - Conventional Finishing 24

4.12 Broad Wovens - Foam Finishing 25

4.13 Beck Dyeing and Continuous Drying of Carpets 26

4.14 Continuous Wet Dyeing and Drying of Carpets 27

4.15 Continuous Foam Dyeing and Air Drying of Carpets 28

4.16 Annual Operating Cost Savings - Tubular Knits 29

4.17 Annual Operating Cost Savings - Broad Wovens 29

4.18 Annual Operating Cost Savings - Beck Carpet Dyeing 30

4.19 Annual Operating Cost Savings - Continuous Carpet Dyeing $\quad 30$

4.20 Summary of Economic Incentives for Retrofit Foam Finishing into Existing Processes 31 
$=$

. 


\subsection{EXECUTIVE SUMMARY}

\subsection{BACKGROUND}

Conventional wet processing of textiles - dyeing, or application of such surface finishes as soil and water repellents, antistatic agents, fire retardants, permanent press agents, and starch - consumes about 0.19 quadrillion Btu's of energy per year, the equivalent of 30 million barrels of oil. Because wet processing involves immersion of the fabric in a water bath, most of the energy used is in the form of heat for drying.

In the newer foam finishing approach, the chemicals for surface finishes are dispersed in a mixture of water and air. The chemicals are concentrated in a relatively small amount of water, and air is injected to form a thick, stable foam. Because little water is involved, drying time and temperature may be drastically reduced.

Arthur D. Little, Inc., conducted an economic and energy audit of foam processing that considered the technical feasibility, reliability, energy savings, and economic incentives for using foam finishing. We monitored four plants that finish textiles (carpets, broad-woven fabrics, and tubular knits). The plants were selected by the developer of the foaming process (United Merchants and Manufacturers, Inc.) to represent a wide range of textile finishing applications.

\subsection{FINDINGS}

The results of the Arthur D. Little audit are favorable from the technical, energy, and economic standpoints. At all sites, foam finishing or foam dyeing performed as well as or better than conventional wet processing. We audited foam processing in textiles as diverse as light tubular knits and heavy carpets. In the plants studied, foam finishing required $37-57 \%$ less energy than conventional wet processing. The only site that did not show energy savings, one processing broadwoven textiles, did not take advantage of the lower moisture pickup inherent in foam finishing when it failed to increase line speed or reduce dryer temperature.

The economic benefits accruing from retrofitting foam finishing on existing dryers are reflected in the increased productivity; the discounted cash flow (dcf) internal rate of return varied from 42 to $140 \%$. Considering energy savings alone, the def internal rate of return varied from 14 to $140 \%$. The capital investment for retrofitting foam processing on existing finishing lines varied from $\$ 45,000$ for the lighter fabrics to $\$ 120,000$ for the carpets.

For new mills, foam processing is even more attractive, since all the increased productivity of foam finishing can be designed into the plant. The equipment designed specifically for foam finishing will be smaller and will cost less than a 
dryer designed for wet finishing. Lower operating costs at lower capital cost present an overwhelming case for foam finishing in all new mills.

Even with retrofitting foam finishing on existing dryers substantial benefits can accrue. In the mill producing tubular knits, the $60 \%$ increase in production rate on the two existing dryers made it possible to eliminate a planned new finishing line yet still attain a major expansion of capacity. Another favorable note is that as plant personnel become more familiar with the capabilities of their foam processing installations, they will save even more energy. For example, one finisher of broadwoven goods reduced its oven temperature by an additional $20 \%$ over most of its foem finishing runs, (a malfunction of the energy monitoring equipment did not allow us to document the additional energy savings). The goods finished at the lower temperature still met all the customer's requirements, however. In carpet dyeing plents, substantial energy savings can be achieved, since foam dyeing can provide better control of dye, and the second washing step, necessary with conventional dyeing, can be eliminated. 


\subsection{OBJECTIVE AND GOALS}

An objective of the U.S. Department of Energy's (DOE) Office of Industrial Programs (OIP) was to expeditiously achieve maximum implementation of existing and new energy conservation technologies. To aid in achieving this goal, the OIP created an "Acceleration Program." The Program's objective was to encourage industry adoption and use of energy-conserving technologies sooner than under normal market conditions. Conservation and Renewable Energy has undertaken several means to promote use of energy conservation technologies. In one such "accelerated acceptance" program, the OIP worked with the equipment suppliers to find users, i.e., host plant operators, to demonstrate the merits of the textile foam process. This technology was made available to users on a cost-sharing basis under the DOE Contract Number DE-FC01-80CS-40334 with United Merchants and Manufacturers, Inc. As participants in the Acceleration Program, the vendor's (in this instance United Merchants and Manufacturers, Inc.) responsibility was to install the process, find users, and publicize the merits of the energy-saving product. The responsibility of the users (the four companies) was to implement the process in their respective plants and to collect operating data for the vendor and $\mathrm{DOE}$. The data collected was to describe the operation of the process including costs, energy consumption, and reliability. Arthur D. Little, Inc., audited the operating performance and economic attractiveness of foam finishing of three types of textiles and prepared this report based upon plant visits and upon data collected at the four plants.

The goal of this project was to provide an independent, third-party technical review (audit) of the technology, operating data, and energy-saving potential of the textile foam process. This report also provides an evaluation of the economic attractiveness of foam finishing, based upon the operating data from all the plants studied. 



\subsection{SCOPE AND APPROACH}

Arthur D. Little monitored four plants:

- Dyeing of Carpets - Galaxy Carpets, Inc., Chatsworth, GA.

- Finishing of Tubular Knits - Health-tex, Inc., Cumberland, RI.

- Finishing of Broad-Woven Fabrics - Harodite Finishing Company, Inc., North Dighton, MA.

- Finishing and Tinting of Broad-Woven Fabrics - Wansona Manufacturing Corporation, Wadesboro, NC.

The audit involved verifying the economic, technological, and energy-conserving factors involved in converting from conventional textile finishing processes to foam finishing. The detailed scope of work involves four items.

\subsection{EVALUATION OF EXISTING PROCESSES}

We prepared a description and evaluation of the existing finishing processes and the modifications necessary for foam finishing. This description is sufficiently detailed to serve as a basis for comparing operating results before and after installing foam finishing.

Figure 3.1 shows a schematic of the conventional finishing of lightweight goods, such as tubular knits, or broad-woven fabrics. The fabric is dipped into a water bath containing the desired chemicals, squeezed between a pair of rolls to remove the excess liquid, and passed through a series of dryers. Even after being squeezed by the padding rolls, the wet-finished goods averaged a pickup of 0.6 to 0.8 pound of water per pound of fabric, all of which had to be removed in the dryers. Evaporation of water from the dryers is energy-intensive, requiring 1,000 to 12,000 Btu per pound of water evaporated. Most dryers in the textile industry require 2,000 to 5,000 Btu per pound of water evaporated.

We evaluated two conventional wet processes for dyeing heavyweight goods such as carpets. The first process, shown in Figure 3.2, is a batch process with an open Beck tank to dye and wash rolls of carpets followed by continuous drying of the carpets on a dryer. The second wet-dyeing process, shown in Figure 3.3, involves a continuous dyeing, steaming, washing, and drying operation. The host plant for carpet dyeing used both wet methods to dye and finish its carpets.

Figures 3.1, 3.2, and 3.3 detail the forms of energy used for wet finishing and the locations of sensors used for monitoring. The major use of energy, about $85 \%$, is in the form of natural gas or steam to provide heat to the dryers. The only other use of energy is to power the electric motors of the dryers and to activate the process

$\triangle$ Arthur D. Little, Inc. 
章

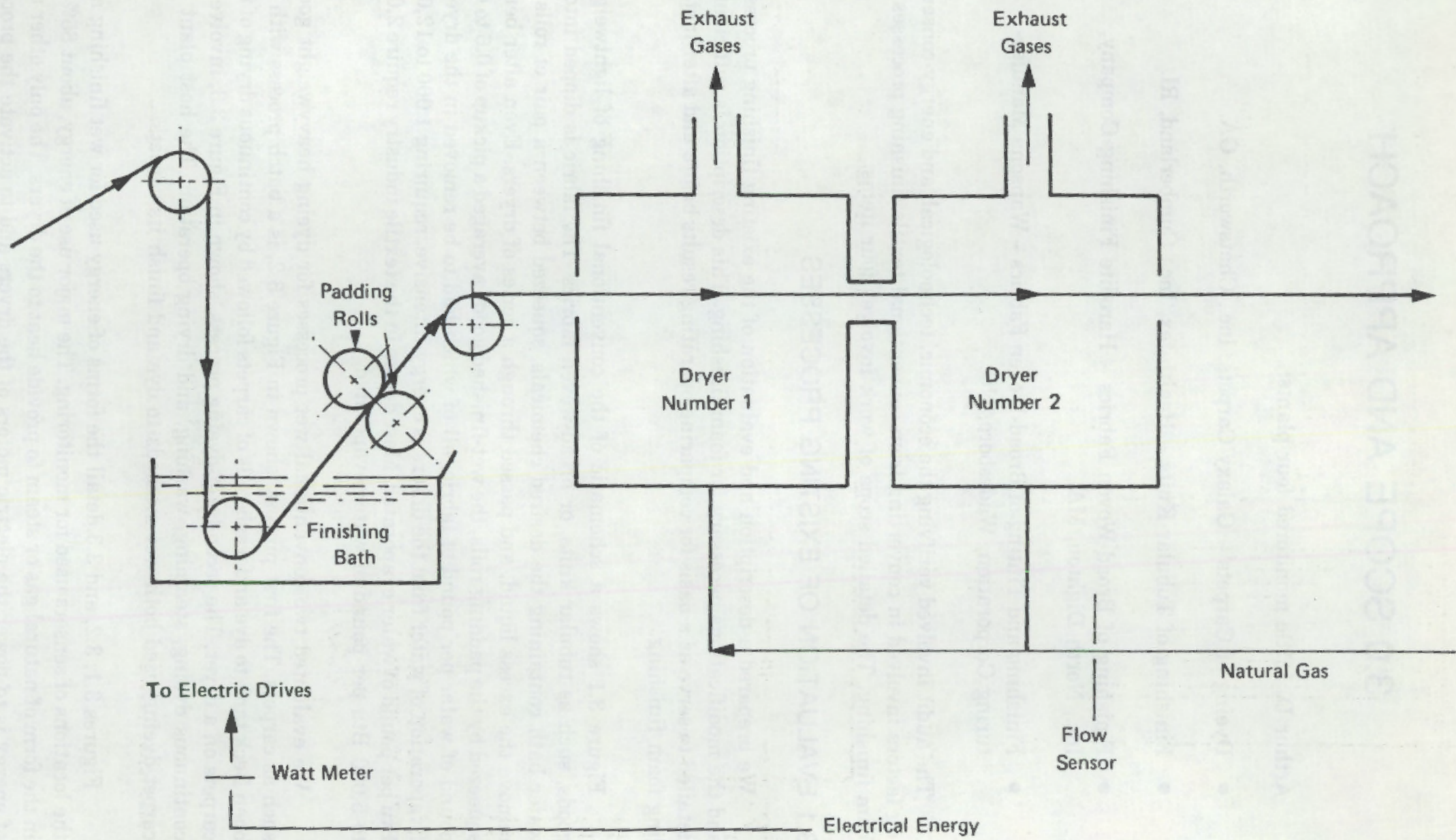

FIGURE 3.1 SCHEMATIC - FINISHING PROCESS FOR WET PICKUP OF CHEMICALS TUBULAR KNITS AND BROAD-WOVEN FABRICS 


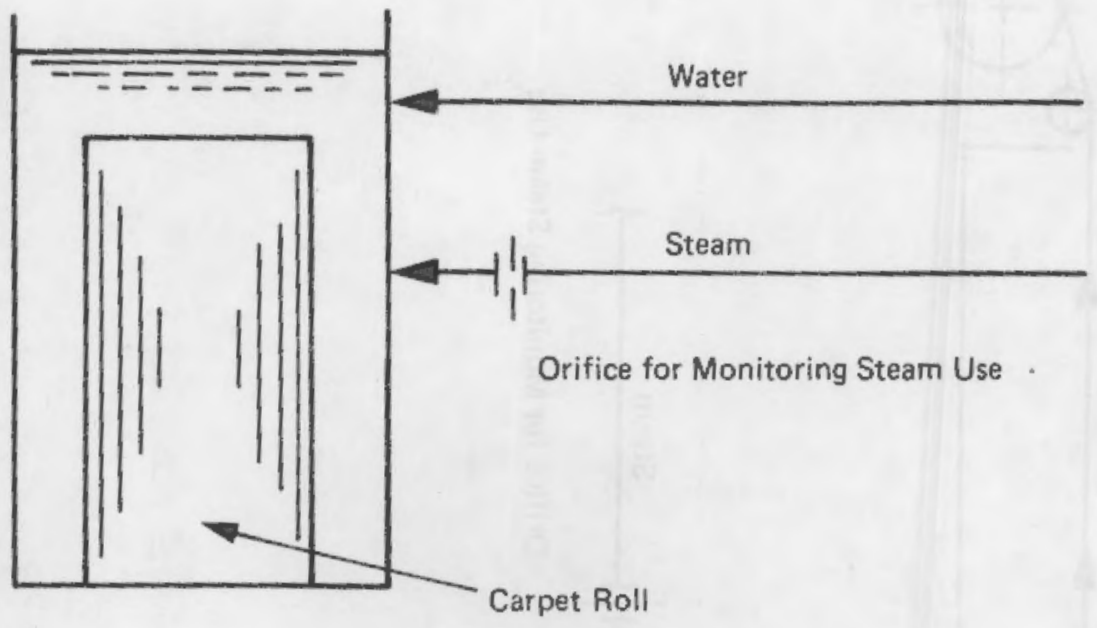

BECK TANK FOR DYEING AND WASHING

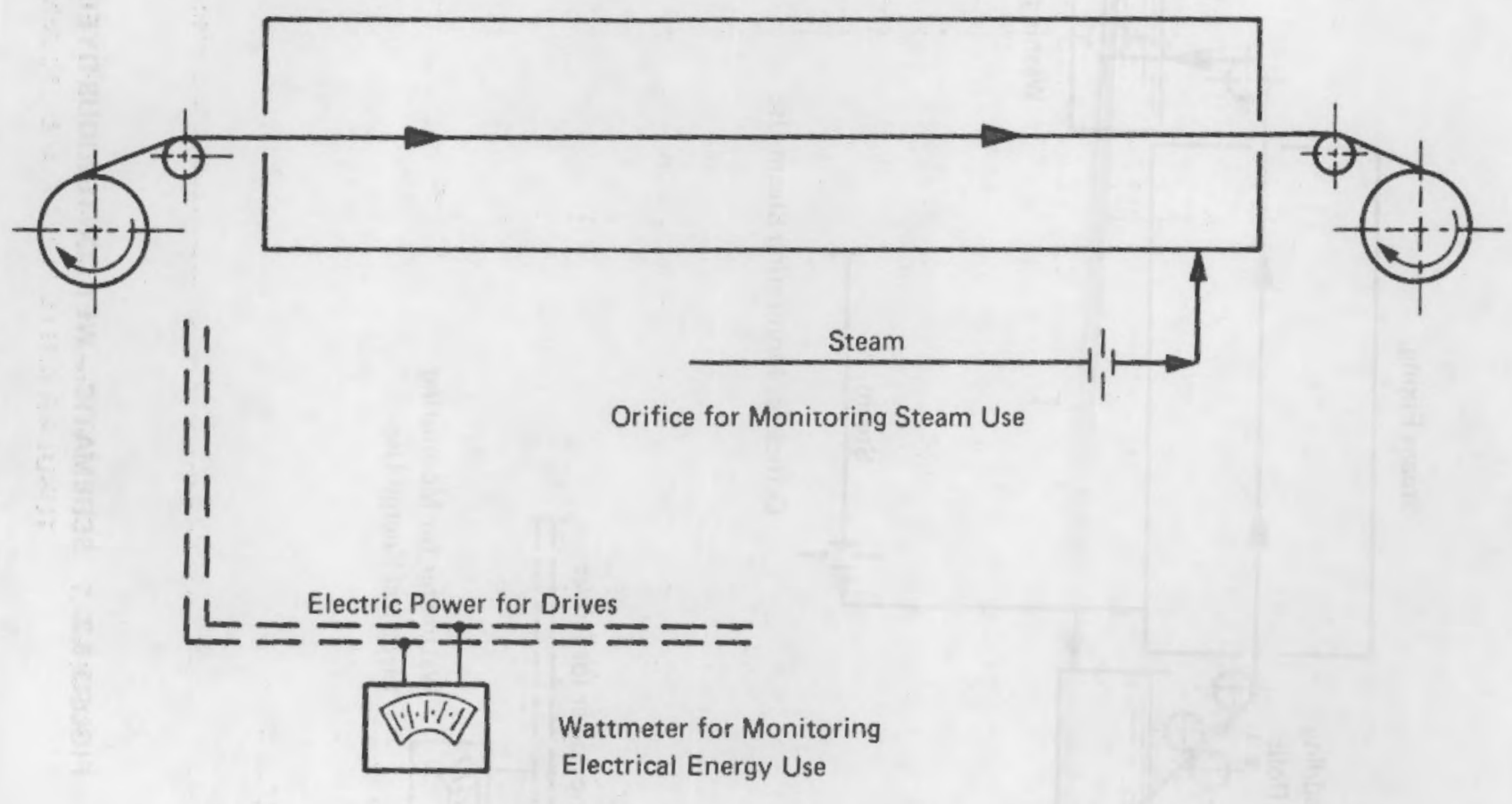

DAYER FOR BECK PROCESS 


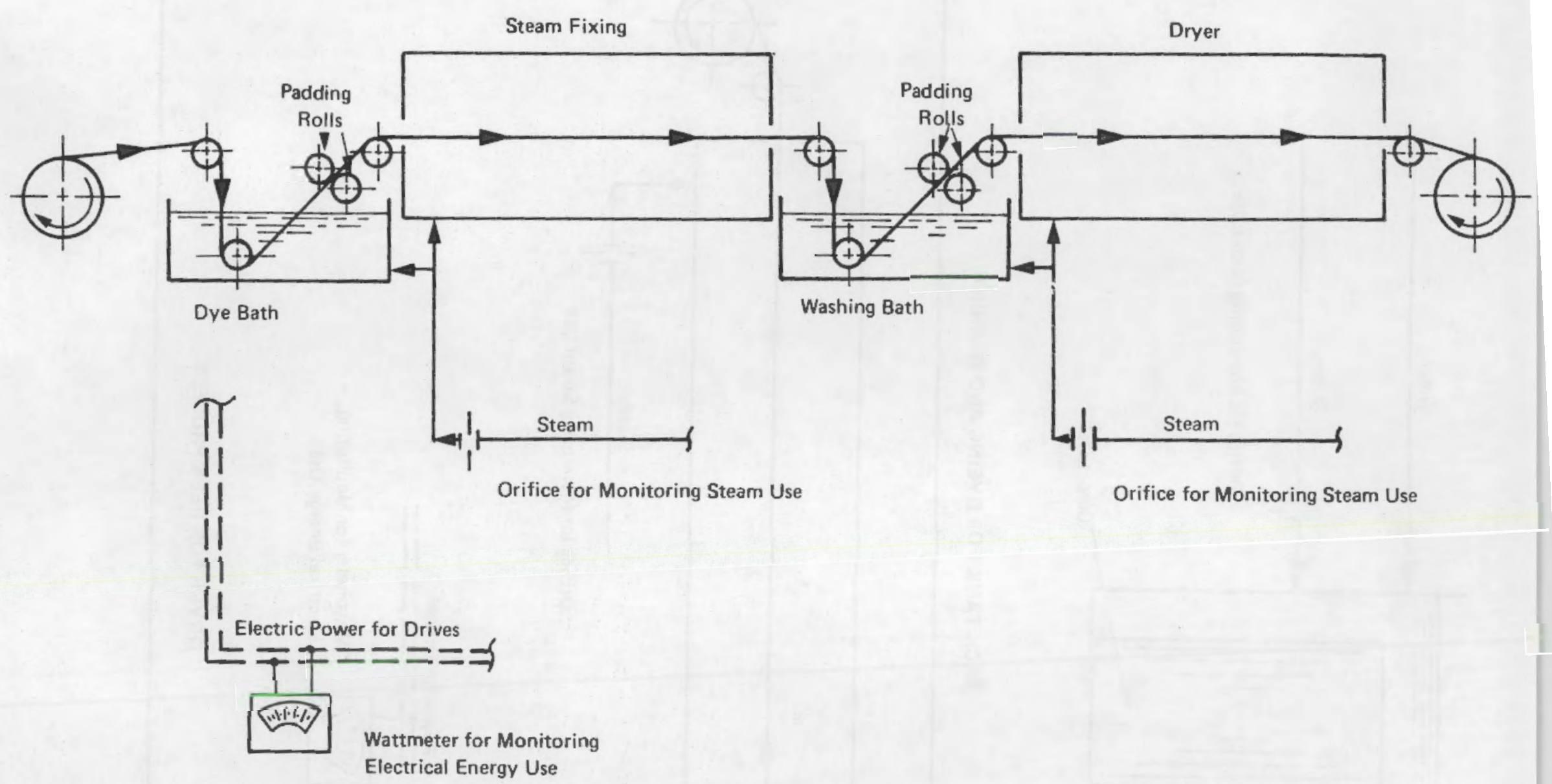

FIGURE 3.3 SCHEMATIC - WET CONTINUOUS DYEING AND DRYING OF CARPETS 
control system. For the audit, the vendor installed at each site a sensor for measuring natural gas or steam use in the dryers, a wattmeter on the line that supplies electric energy to the dryers, and a monitor (manufactured by the J.W. Sweet Company of Columbia, SC), that recorded total energy consumption, both thermal and electric. Personnel at each plant recorded, from meters already installed, total yardage produced and fabric types.

\subsection{REVIEW AND EVALUATION OF FOAM FINISHING}

To ensure the fairest comparison between foam finishing and conventional technology, the same finishing line and a similar product mix were used for both processes in the respective plants. Thus, the audit measured the same type of energy consumption on the same dryer with the same sensors and recorders for both processes. The order of scheduling foam or wet processing was randomized, so any operating improvements would apply equally to both processes. Every possible step was taken to ensure that the only substantive changes in operating procedures were related to the method of application of the finish to the goods.

Figures 3.4 and 3.5 present a schematic view of the finishing operations for modified foam processing of lightweight and heavyweight goods. The major changes relate to the application of the foam finish and the elimination of the water bath. The goods typically picked up only half as much moisture as in wet finishing and dried much more readily. The operators at one host plant found that they could increase the speed of the line by $60 \%$ (from $25 \mathrm{yd} / \mathrm{minute}$ to $40 \mathrm{yd} / \mathrm{minute}$ ) and still dry the goods to the same final dryness. Other plants combined increased line speed with lower oven temperatures. In this manner, the host plants not only reaped significant energy savings, but substantial cost savings on labor and annualized capital charges by increasing production rates.

The unique feature of foam finishing is to replace most of the water in the finish solution with air, and thus save on energy needed to dry the goods. The foam, similar in consistency to shaving cream, typically has five parts of air to each part of liquid. On a volume basis, however, the foam is formulated to have the same amount of finishing chemicals as the wet finishes. Thus, the fabric picks up the same amount of chemicals as with wet finishing, but much less water.

The vendor chose to use a foam generator manufactured by the Textile, Rubber and Chemical Company of Dalton, GA. A number of other companies manufacture foam generators including the following:

- Eze, Inc., Dalton, GA.

- Latex Equipment Systems, Daiton, GA.

- SKG Industries, Reading, PA.

- Mondo (European)

- Eurofoamer (European)

- Capin Machinery (European)

Arthur D. Little, Inc. 


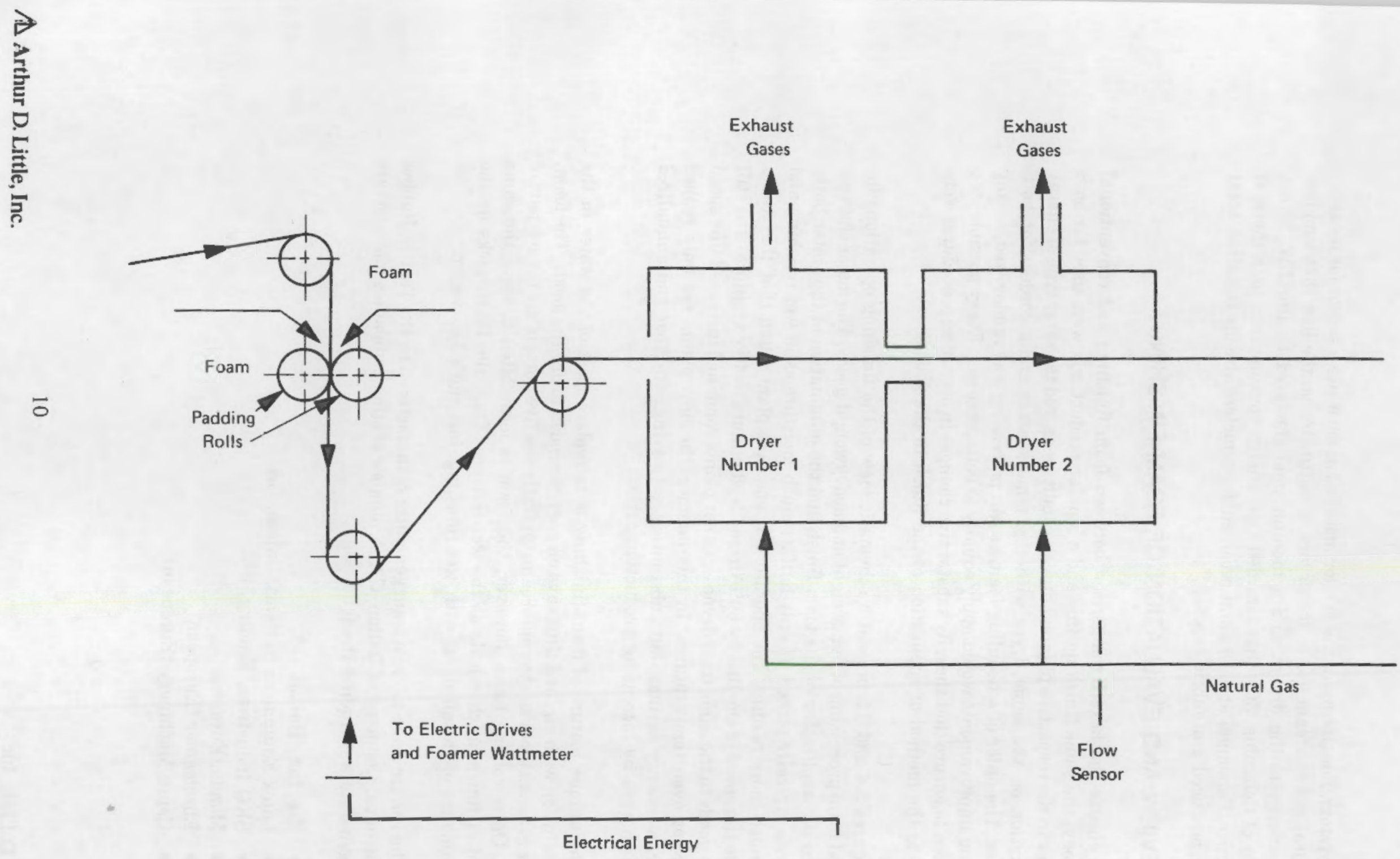

FIGURE 3.4 SCHEMATIC - FINISHING PROCESS FOR FOAM PICKUP OF CHEMICALS TUBULAR KNITS AND BROAO-WOVEN FABRICS 


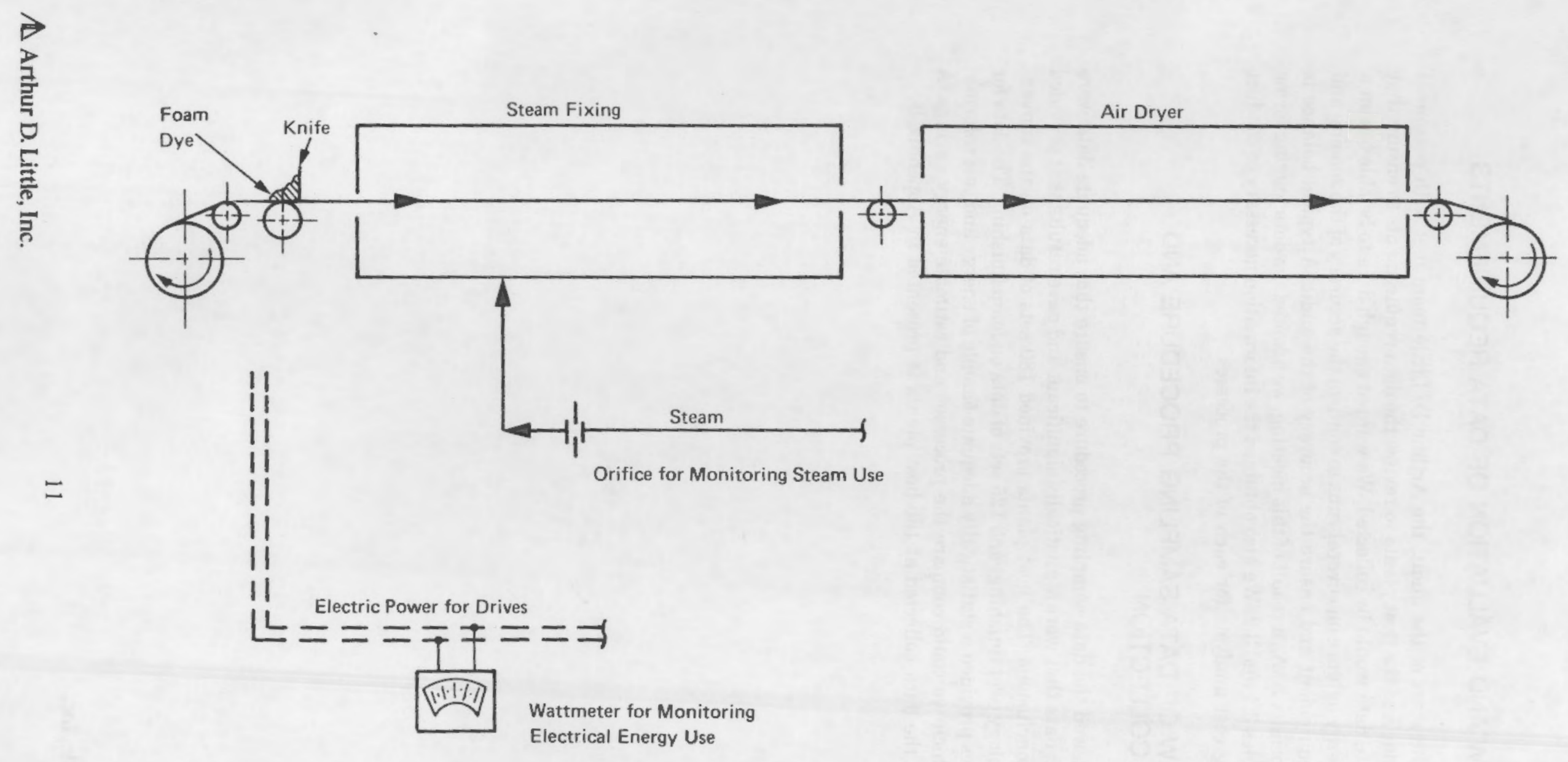

FIGURE 3.5 SCHEMATIC - CONTINUOUS FOAM DYEING AND AIR DRYING OF CARPETS 


\subsection{REVIEW AND EVALUATION OF DATA REQUIREMENTS}

Before the start of the audit, the Arthur D. Little team met with personnel from the vendor and the host plants to review the data requirements to ensure that all appropriate data would be collected. We wanted enough data to be able to run a water and energy balance on several runs to confirm the accuracy of the sensing and monitoring equipment and ensure the accuracy of the audit. A typical balance is shown in Appendix A. As a result of this meeting, we adopted the data logging forms shown in Tables 3.1 and 3.2. We also obtained the information necessary to conduct the operating cost analysis for each of the processes.

\subsection{REVIEW OF DATA SAMPLING PROCEDURE AND DATA COLLECTION}

We reviewed the data sampling procedure to ensure that adequate data were collected, i.e., data that were statistically significant and gave results that provided convincing conclusions. The host plants provided 180 sets of data on the conventional technology (wet finishing) and 125 sets of data on foam finishing. The data for both processes provided a statistically adequate sample of energy and cost information from which we could compare the processes and estimate energy savings. A summary of the data collected at the host plants is presented in Appendix B. 
TABLE 3.1

FOAM FINISHING TEST RESULTS

$\because \therefore$ Tubular Knits (Health-tex) _.____ DETE_

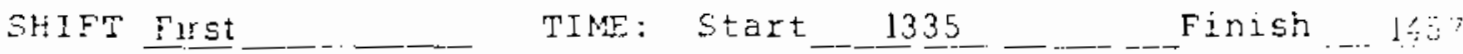

FRAME SYECIFICAIION AND LAYOUT

FABRIC SPECIFICRTIG:

Make Tubular Textile Corp.

No. Zomes Three

Heat Recovery None - - -

Typo Heat Natural Ges_...... -

Construction. 50/Poly 50/Cutom TersexWeight 1,062

width 28 :

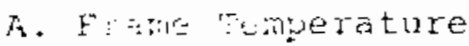

$$
\begin{aligned}
& \text { rone } \neq 1 \\
& \text { urne } \neq 2 \\
& \text { zone } \neq 3
\end{aligned}
$$

B. Pritre Speed

C. Steam consumed

D. Gas Consumed

E. A.C. Power Consumed

F. Total Energy

G. Moisture - Before Pad

H. Moisture - After Pad

J. Moisture - Leaving Frame

K. Type of Finish

i. Volure of Finish Consumed

M. Yirds processed

Meter yas: End 8035

Meter Yas:Start 6011

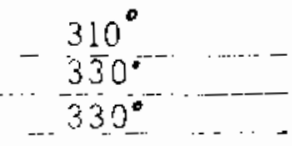

25 Y.P.M.

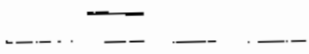

33.37 S. C.F.H.

$2.71-K \underline{w}$.

36.01 Therms

-. .03\% ....

$-59 \%$

- $-\underline{0 \%}$

- P-3

55.7 Gals.

2024 Yds.

N. Exhaust Stacks

No. 1

No. 2

No. 3

No. 4

Aribient

\begin{tabular}{|c|c|c|c|c|c|}
\hline $\begin{array}{l}\text { VOI. } \\
\text { CFM }\end{array}$ & $\begin{array}{l}\text { Temp. } \\
O F\end{array}$ & $\begin{array}{l}\text { Dew } \\
\text { point of }\end{array}$ & $\begin{array}{l}\text { VOI. } \\
\text { CFII }\end{array}$ & $\begin{array}{l}\text { Semp. } \\
\text { of }\end{array}$ & $\begin{array}{l}\text { Dew } \\
\text { Point of }\end{array}$ \\
\hline 3850 & $315^{\circ}$ & & & & \\
\hline 3900 & $320^{\circ}$ & 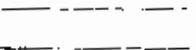 & & & $\cdots$ \\
\hline 3900 & $320^{\circ}$ & 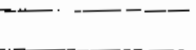 & & & \\
\hline & & & & & $\cdots$ \\
\hline & $124^{\circ}$ & & & & \\
\hline
\end{tabular}

Surface

Misc: 
Plant Galaxy Carpet Mills, Inc. Date 7-22-82

shift 3rd, lot a 2nd

Ydo. Dyed $\frac{117,4501 \mathrm{bs} .}{48,4535.4 .}$

Shade N.1
Time: Start 11:00 p.m. - Finish 11:00 p.m. Carpet specifications

Construction Cut Loop

Weight Avg. 37.78 ozs./sq. yd. wat th
Energy Consumption (B.T.U. Equivalents)

Process

Beck Wet Continuous Foam Continuous

A. Dyeing

1. Water Useage

2. Steam Useage

3. Electricity*

4. Fuel (Lift truck useage)
$0.62 \mathrm{gals} . / 1 \mathrm{~b}$.

2.27 gals.7s.y.

5,552 BTUS/1b.

13,458 BTUS/S.Y.

130 BTUS/Ib.

315 BTUS/S.Y.

$18.17 \mathrm{BTCs} / 1 \mathrm{~b}$. 45.07 BTUS/s.y.

B Drying

1. Water Useage

Wet Out Box

2. Steam (Radiators)

(Steam Fixation)

$\overline{\text { NTA }}$

3. Electricity

Total Energy Consumption

*Should include where applicable:

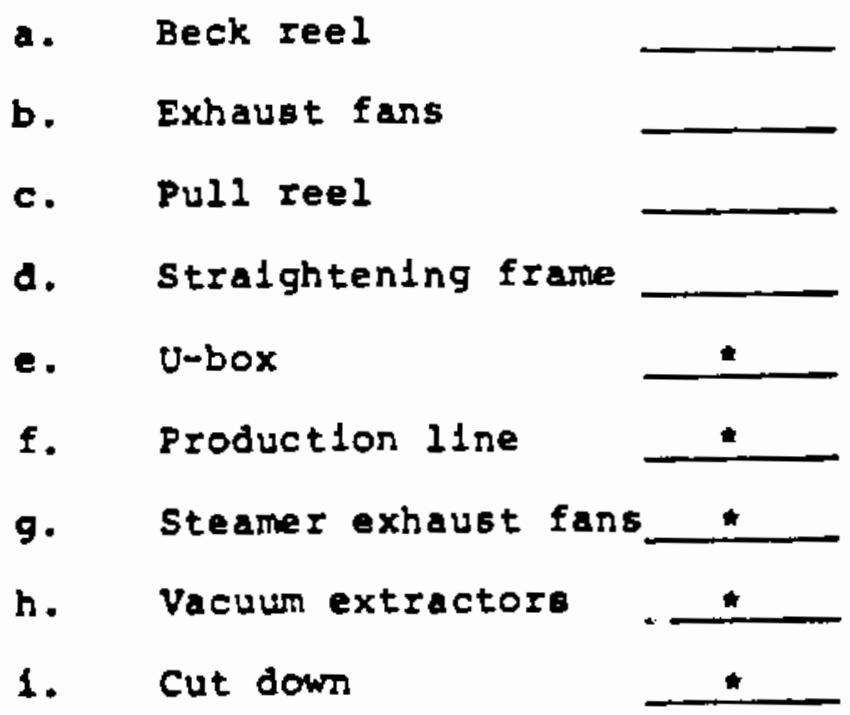

j. Dye make-up mixers

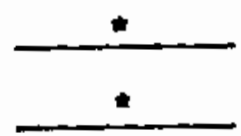

k. Backbeater

1. Traverse mechanism

m. Fosm machine

n. Tenter track

- Backbeater and lint collector

P. Roll up 


\subsection{FINDINGS}

\subsection{COMPARISON OF PROCESS ENERGY USE}

The primary advantage of foam finishing over wet finishing is that the fabrics pick up much less water when being coated with the finishing chemicals. Foam finishing does not add as much water to the fabric since some of the diluting agent in the foam is air. Table 4.1 details the average water pickup; the foam-finished fabrics picked up 48 to $53 \%$ less water than the wet-finished fabrics. The difference in water pickup in dyeing and finishing carpets is even more pronounced, because with foam processing, color can be more precisely controlled and a second bath to wash out excess dye is not necessary. With careful control, this lower water pickup can be transferred directly to lower energy consumption in the dryer. To ensure the addition of an equal amount of finish chemicals to the goods, the finishing solution before foaming contains twice to three times the concentration of chemicals as in wet processing. The air in the foam gives it greater bulk, thus assuring even distribution of chemicals in the fabric for a high quality finish.

TABLE 4.1

\section{MOISTURE PICKUP WET VS FOAM FINISHING}

\begin{tabular}{lccccc} 
& \multicolumn{2}{c}{$\begin{array}{c}\text { Water Picked Up Per } \\
\text { Lb Dry Goods (Lb) }\end{array}$} & & \multicolumn{2}{c}{$\begin{array}{c}\text { Reduction in Water Pickup } \\
\text { By Foam Finishing }\end{array}$} \\
\cline { 2 - 2 } Type of Textile & Wet Finished & Foam Finished & & $($ Lb) & $(\%)$ \\
Tubular Knits & 0.52 & 0.25 & & 0.27 & 52 \\
Broad Woven (Harodite) & 0.77 & 0.36 & & 0.41 & 53 \\
Broad Woven (Wansona) & 0.87 & 0.45 & & 0.42 & 48 \\
Carpets (Beck Process) & 7.00 & 1.7 & & 5.30 & 76 \\
Carpets (Continuous Process) & 7.91 & 1.7 & & 6.21 & 79
\end{tabular}

Table 4.2 summarizes how well the reduction in moisture content achieved through foam finishing correlates with lower energy consumption. Energy savings ranged from 37 to $57 \%$ for plants where some dryer adjustments were made. The only site that did not achieve energy savings did foam finish their goods, but did not lower the temperature setting on the dryers to take advantage of the lower moisture content of the incoming fabric. Because this plant neither lowered the dryer temperature nor increased the finishing line speed, it alone failed to achieve energy savings. Even though the energy savings for the lighter goods ranged from 37 to $42 \%$, the savings were lower than the decrease in moisture content of the wet fabrics. These data indicate that with further careful adjustments, plants could realize higher energy savings in the dryers by using a combination of: 
TABLE 4.2

\section{ENERGY USED TO FINISH FABRICS}

\begin{tabular}{|c|c|c|c|c|c|}
\hline \multirow{3}{*}{ Type of Textile } & \multirow{3}{*}{$\begin{array}{c}\text { Wet Finishing } \\
\text { Btu/1b Finished } \\
\text { Fabric }\end{array}$} & \multirow{3}{*}{$\begin{array}{c}\text { Foam Finishing } \\
\text { Btu } / \mathbf{b} \text { Finished } \\
\text { Fabric }\end{array}$} & \multirow{3}{*}{$\begin{array}{c}\text { Energy Saving } \\
\text { Btu/lb Finished } \\
\text { Fabrit }\end{array}$} & \multicolumn{2}{|c|}{ Percent Reduction } \\
\hline & & & & Energy & Water \\
\hline & & & & Consumption & Pickup \\
\hline Tubular Knits & 3,750 & 2,370 & 1,380 & 37 & 52 \\
\hline Broad Woven (Harodite) ${ }^{*}$ & 850 & 490 & 360 & 42 & 53 \\
\hline Broad Woven (Wansona) * * & 12,200 & 12,200 & 0 & 0 & 48 \\
\hline Carpets (Beck Process) & $\uparrow 3,600$ & 8.600 & 5.000 & 37 & 76 \\
\hline Carpets (Continuous Process) & 20.200 & 8,600 & 11,600 & 57 & 79 \\
\hline
\end{tabular}

*The Harodite finishing line has been well adjusted for a uniform product, and is very efficient.

** The Warsona finishing line handles a wide variety of textile widths and weights. The dryers have been set up for the heaviest weight material, so energy consumption for lighter materials is high. 
1. Further lowering the temperature in the dryer, and

2. Further increasing the speed of fabric passing through the dryer.

One plant processing broad-woven goons (Harodite) lowered the air temperature in its dryer from $300^{\circ} \mathrm{F}$ for wet finishing to $220^{\circ} \mathrm{F}$ for foam finishing in test runs documented by the monitoring equipment. In further trials with foam finishing, plant personnel lowered the dryer temperature to $190^{\circ} \mathrm{F}$ and dried the fabric to the same final moisture levels. Although we could not document the additional energy savings because the monitoring equipment malfunctioned during these runs, it appears that further energy savings were achieved.

The site finishing tubular knits (Health-tex) increased the speed of the finishing line by $60 \%$ from $25 \mathrm{yd} /$ minute with wet finishing to $40 \mathrm{yd} /$ minute for foam finishing. This increase in speed resulted in an energy saving of $37 \%$; had the host plant also lowered the air temperature in the dryer, the percent energy savings might well have approached the percent reduction in moisture.

The average efficiencies of the various dryers varied from 7 to $78 \%$ during the drying of wet-finished goods, as is shown in Table 4.3. The plants with very low average dryer efficiencies are probably overdrying many of their goods. For example, the dryer efficiencies for tubular knits varied from $12 \%$ for the lighter weight goods to $55 \%$ for the heaviest weight goods, with an average of $18 \%$ on the overall product mix. (See Appendix B for dryer efficiency on individual runs.) It appears that plants set the dryer for their heaviest-weight goods and did not lower the temperature settings for the lighter-weight goods that account for most of their production. The plant with the $78 \%$ average dryer efficiency (Harodite) finishes only one weight of goods and has carefully set the dryer conditions for this one product. The knowledge gained and attention given to energy consumption during this program should help the plants schedule their finishing runs to achieve even lower energy consumption in the future.

TABLE 4.3

\section{DRYER EFFICIENCIES*}

$\begin{array}{lc}\text { Type of Textile } & \begin{array}{c}\text { Average Dryer Efficiency* } \\ \text { During Wet Finishing (\%) }\end{array} \\ \text { Tubular Knits } & 18 \\ \text { Broad Woven (Harodite) } & 7 \\ \text { Broad Woven (Wansona) } & 78 \\ \text { Carpets (Beck Process) } & 35 \\ \text { Carpet (Continuous Process) } & 35\end{array}$

\footnotetext{
*Efficiency is defined as the thermal energy required to evaporate the water from the fabric, divided by the total thermal energy supplied to the dryer.
} 
Table 4.4 details the potential annual energy savings if all production were done by foam finishing at each plant. The table gives a breakclown of energy use and the percentage reduction for both thermal energy and electric energy as well as the total energy savings reported in Table 4.2. The plant that achieved its energy savings by increasing the finishing line speed by $60 \%$ achieved similar percentage reductions of both its thermal and electric energy consumption. The plant that achieved energy savings by a combination of increased finishing line speeds and reduced dryer temperatures (shown in Table 4.5) showed a larger percentage of thermal savings than savings in electric energy. The site that converted from a batch process (Beck carpet dyeing) to continuous foam dyeing (shown in Table 4.6) actually increased electric energy consumption because of the continuous handling of the carpet rolls, but still had a $37 \%$ reduction in overall energy use because less heat was required. Conversion of the wet continuous dyeing operation to foam continuous dyeing (Table 4.7) showed a lower electric energy consumption because the washing step after steam setting was eliminated. This conversion also showed the most striking overall energy reduction ( $57 \%$ ) largely because foam dyeing can provide better control of the amount of dye added to the carpets. The dye can be fixed in the steaming step, eliminating the need for washing the carpets after the steaming step and then redrying the washed carpets.

TABLE 4.4

ANNUAL ENERGY CONSUMPTION FOR FINISHING TUBULAR KNITS

Basis: $10,671,774$ Yards Processed in 1982

$\begin{array}{lccc}\text { Item } & \begin{array}{c}\text { Natural Gas } \\ \mathbf{1 0}^{\mathbf{9}} \text { Btu's }\end{array} & \begin{array}{c}\text { Electric Energy } \\ \text { Megawatt Hours }\end{array} & \begin{array}{c}\text { Total Energy } \\ \mathbf{1 0}^{\mathbf{9}} \text { Btu's }\end{array} \\ \text { Conventional Wet Finishing } & 18.8 & 484 & 23.1 \\ \text { Foam Finishing } & 11.9 & 25 ! 9 & 14.6 \\ \text { Reduction in Energy Use } & 6.9 & \mathbf{2 2} 5 & 8.5 \\ \text { Percent Reduction in Energy Use } & 37 & 31 j & 37\end{array}$

* Conversion of 1 kilowatt-hour into the 10,500 Btu's of thermal energy required to generate it. 
TABLE 4.5

ANNUAL ENERGY CONSUMPTION FOR FINISHING BROAD WOVENS

Basis: 14,000,000 Yards Processed in 1982

*Conversion of 1 kilowatt-hour into the 10,500 Btu's of thermal energy required to generate it.

TABLE 4.6

ANNUAL ENERGY CONSUMPTION FOA BECK DYEING OF CARPETS COMPARED WITH FOAM DYEING

Basis: $15,840,000$ Square Yards Processed in 1982

$\begin{array}{lccr}\text { Item } & \begin{array}{c}\text { Steam Use } \\ \mathbf{1 0 ^ { 9 }} \text { Btu's }\end{array} & \begin{array}{c}\text { Electric Energy } \\ \text { Megawatt Hours }\end{array} & \begin{array}{c}\text { Total Energy* } \\ \mathbf{1 0}^{9} \text { Btu's }\end{array} \\ \text { Beck Dyeing } & 186 & 2,851 & 216 \\ \text { Foam Dyeing } & 99.6 & 3,484 & 136 \\ \text { Reduction in Energy Use } & 86.4 & (633) & 80 \\ \text { Percent Reduction in Energy Use } & 47 & (22) & 37\end{array}$

"Conversion of 1 kilowatt-hour into the 10,500 Btu's of thermal energy required to generate it. 
TABLE 4.7

\section{ANNUAL ENERGY CONSUMPTION FOR WET CONTINUOUS DYEING OF CARPETS COMPARED WITH FOAM DYEING}

Basis: $15,840,000$ Square Yards Processed in 1982

\author{
item \\ Wet Continuous Dyeing \\ Foam Dyeing \\ Reduction in Energy Use \\ Percent Reduction in Energy Use
}

$\begin{array}{ccc}\begin{array}{c}\text { Steam Use } \\ 10^{9} \text { Btu's }\end{array} & \begin{array}{c}\text { Electric Energy } \\ \text { Megawatt Hours }\end{array} & \begin{array}{c}\text { Total Energy } \\ 10^{9} \text { Btu's }\end{array} \\ 277 & 4.229 & 321 \\ 99.6 & 3,484 & 136 \\ 177.4 & 745 & 185 \\ 64 & 18 & 58\end{array}$

*Conversion of 1 kilowatt-hour into the 10,500 Btu's of thermal energy required to generate it.

\subsection{COMPARISON OF ECONOMICS}

The economics of the conversion of existing wet-finishing lines to foam-finishing lines are extremely attractive. Production cost savings in labor and energy as well as annualized capital costs were included in the analysis. Although not documented, additional savings appeared to have occurred through reduced use of chemicals. Table 4.8 summarizes the operating cost savings that result from the retrofitting of foam finishing on existing ninishing lines. The savings on operating costs on lighter-weight goods vary from 16 to $36 \%$. The plant nnishing tubular knits showed the largest reduction in operating costs $(36 \%)$ because it took advantage of the lower energy requirements during drying by increasing the finishing line speed by $60 \%$. Table 4.8 also summarizes the operating cost savings that result from retrofitting foam dyeing on existing dyeing lines for carpets. The savings on operating costs ranged from 28 to $38 \%$.

TABLE 4.8

OPERATING COSTS OF FINISHING OPERATIONS

\begin{tabular}{lccrrr} 
& \multicolumn{2}{c}{ Operating Costs $-\$ / 1000$ Vds } & & \multicolumn{2}{c}{$\begin{array}{c}\text { Reduction by Using } \\
\text { Foam Finishing }\end{array}$} \\
\cline { 2 - 6 } Type of Textile & $\begin{array}{c}\text { Wet } \\
\text { Finishing }\end{array}$ & $\begin{array}{c}\text { Foam } \\
\text { Finishing }\end{array}$ & & $(\$)$ & $(\%)$ \\
\cline { 4 - 7 } Tubular Knits & $\$ 71.67$ & $\$ 45.27$ & & $\$ 26.40$ & 36 \\
Broad Wovens & 13.40 & 11.20 & 2.20 & 16 \\
Carpets (Beck Process) & 137.63 & 98.88 & 38.75 & 28 \\
Carpets (Continuous Process) & 158.84 & 98.88 & & 59.96 & 38
\end{tabular}


Tables 4.9 and 4.10 detail the operating costs for the wet and foam finishing of tubular knits. This plant achieved its energy savings solely by increasing the speed of its finishing line. The plant finishing broad-woven fabrics gained most of its energy savings by reducing the dryer temperature. It could increase the line speed by only $18 \%$ because of drive mechanism limitations. Even though it achieved a $42 \%$ reduction in energy use, it lowered its overall operating costs by only $16 \%$. This example shows that it is highly advantageous to use the extra capacity of the dryer that foam finishing offers by increasing the finishing line speed. Tables 4.11 and 4.12 detail these operating costs for wet and foam finishing of broad-woven fabrics.

In comparing the batch process Beck dyeing (Table 4.13) with retrofitting foam dyeing on an existing continuous dyeing line, we found an operating cost saving of $28 \%$. This saving was largely due to a reduction in energy use, but carpet dyeing is so energy-intensive that a saving in this one category results in dramatic overall savings. The other comparison is between a continuous line set up for either wet dyeing or foam dyeing of carpets. In this case, the energy savings were even more dramatic; the overall operating cost reduction reached $38 \%$. The major reasons for the dramatic reduction in energy use with foam dyeing centered on the more controlled application of the dye before the carpets were steamed to fix the dye. When the dye was applied by foam, the carpets did not have to be washed afterward (adding new water that must be removed), and the hot carpets from the steamer could simply be cool-air dried. When the dye was applied by dipping in a dye bath, excess dye solution had to be washed from the carpet after steam setting. The washed carpet then required hot air drying that dramatically increased energy consumption. Tables 4.14 and 4.15 present the detailed breakdown for operating costs on wet-continuous and foam-continuous dyeing. Details of the runs are shown in Appendix B.

Looking at the capital investments required to reap this saving, we find two different investments required for the lightweight and heavyweight goods. The capital requirement for the light goods retrofit was $\$ 30,000$. Even though it was difficult to estimate installation costs, we chose a relatively low installation factor of $50 \%$ additional investment to bring the installed cost to $\$ 45,000$. The installation estimate is low because most of the retrofit equipment is assembled before delivery to the plant. The foamer requires little installation and requires only normal service electric power and low-pressure compressed air if available ta small compressor can be part of the foamer cart if compressed air is not availablel. For the carpet installation, the investment is higher $(\$ 80,000)$ largely because of the larger rolls required. Installation of larger rolls should bring the installed cost to $\$ 120,000$, using the $50 \%$ factor for installation.

These capital investments produce the annual savings in operating costs summarized in Tables 4.16 through 4.19. These savings ranged from $\$ 30,400$ for broad wovens to $\$ 949,700$ for continuous dyeing of carpets. In all cases except continuous dyeing of carpets, the largest savings were in labor and energy costs. With continuous dyeing of carpets, no labor was saved since the line speed was not increased, but carpet dyeing is so energy-intensive that the energy savings alone produced the largest savings at any plant. 
TABLE 4.9

\section{TUBULAR KNITS - CONVENTIONAL FINISHIVG}

Basis: Line Speed - 25 Yards/Minute

(Raw Materials are the Same as Foam Finishing -

Same Pickup of Finishing Chemicals)

Item

Variable Costs

Direct Labor

$\{3$ persons -

3 shifts)

Supervisory

(1/4 person * -

1 shift)

Maintenance

(1/2 person * -

1 shift

Labor Overhead

(40\% of labor)

TOTAL LABOR

Energy

Natural Gas

Electrical Energy

TOTAL ENERGY

TOTAL VARIABLE

Fixed Costs

Dryer Leasing

Plant Overhead

(60\% of labor costs)

TOTAL FIXED

TOTAL OPERATING COSTS WITHOUT CHEMICALS

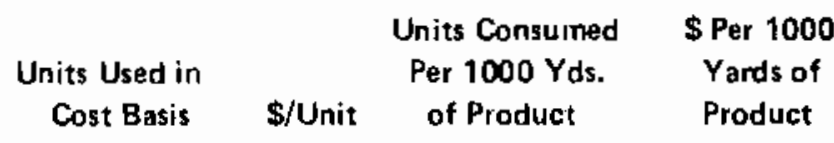

Hours $\quad \$ 11.60 \quad 2.00 \quad \$ 23.20$

$\begin{array}{llll}\text { Hours } & 16.00 & 0.0555 & 0.89\end{array}$

$\begin{array}{llll}\text { Hours } & 11.60 \quad 0.1111 & 1.29\end{array}$

10.15

35.53

$\begin{array}{llcr}\text { Millions Btu } & 6.22 & 1.765 & 10.98 \\ \text { Kilowatt hours } & 0.066 & 45.41 & 3.00\end{array}$

13.98

49.51

Months $\quad 430.00 \quad 0.002249^{* *} \quad 0.97$

21.20

*Personnel have other duties.

** Based on 1981 production of 5,335,887 yards of finished fabric per finishing line.

$\triangle$ Arthur D. Little, Inc. 
TABLE 4.10

TUBULAR KNITS - FOAM FINISHING

Basis: Line Speed 40 Yards/Minute

(Raw Materials are the Same as Wet Finishing -

Same Pickup of Finishing Chemicals)

Item

Variable Costs

Direct Labor

(3 persons -

3 shifts)

Supervisory

(1/4 person ** -

1 shift)

Maintenance

(1/2 person ** -

1 shift)

Labor Overhead

(40\% of labor)

TOTAL LABOR

\section{Energy}

Natural Gas

Electrical Energy

TOTAL ENERGY

TOTAL VARIABLE

\section{Fixed Costs}

Foaming Equipment

(10\% of Capital Cost/

Year) **

Dryer Leasing

Plant Overhead

(60\% of labor costs)

TOTAL FIXED

TOTAL OPERATING COSTS

WITHOUT CHEMICALS

$\begin{array}{cccc} & & \text { Units Consumed } & S \text { Per } 1000 \\ \text { Units Used in } & & \text { Per } 1000 \text { Yds. } & \text { Yards of } \\ \text { Cost Basis } & \text { S/Unit } & \text { of Product } & \text { Product }\end{array}$

Hours $\quad \$ 11.60 \quad 1.25 \quad \$ 14.50$

$\begin{array}{llll}\text { Hours } & 16.00 & 0.03472 & 0.56\end{array}$

Hours

$11.60 \quad 0.06944$

0.81

6.34

22.21

Millions of Btu

$6.22 \quad 1.12$

6.97

Kilowatt hours

$0.066 \quad 24.32$

1.60

Months

$430.00 \quad 0.001406^{* * *}$

0.60

13.32
375./ $0.001406^{* * *} \quad 0.53$

month

* Personnel have other duties.

** $\$ 45,000$ for conversion costs including foamers, controls, horizontal pad rolls, and installation.

*** Based on an increased speed from $25 \mathrm{yd} / \mathrm{minu}$ te to $40 \mathrm{yd} / \mathrm{minute}$.

A Arthur D. Little, Inc. 
TABLE 4.11

\section{BROAD WOVENS - CONVENTIONAL FINISHING}

Basis: Line Speed - 85 Yards/Minute

(Raw Materials are the Same as Foam Finishing -

Same Pickup of Finishing Che micals)

Item

\section{Variable Costs}

Direct Labor

(2 persons -

3 shifts)

Supervisory

(1/4 person * -

1 shift)

Maintenance

11/2 person* -

1 shift)

Labor Overhead

( $40 \%$ of labor)

TOTAL LABOR

\section{Energy}

Natural Gas

Electrica!

TOTAL ENERGY

TOTAL VARIABLE

\section{Fixed Costs}

Plant Overhead

(60\% of labor costs)

TOTAL FIXED

TOTAL OPERATING COSTS WITHOUT CHEMICALS

*Personnel have other duties.

$\begin{array}{cccc}\text { Units Used in } & & \begin{array}{c}\text { Units Consumed } \\ \text { Per } 1000 \text { Yds. }\end{array} & \begin{array}{c}\$ \text { Per } 1000 \\ \text { Yards of }\end{array} \\ \text { Cost Basis } & \$ / \text { Unit } & \text { of Product } & \text { Product }\end{array}$

$\begin{array}{llll}\text { Hours } & \$ 11.60 & 0.392 & 4.55\end{array}$

$\begin{array}{llll}\text { Hours } & 16.00 & 0.0163 & 0.26\end{array}$

$\begin{array}{llll}\text { Hours } & 11.60 & 0.0327 & 0.38\end{array}$

2.08

7.27

$\begin{array}{llll}\text { Millions Btu } & 6.22 & 0.264 & 1.64\end{array}$

Kilowatt hours $\quad 0.066 \quad 1.92 \quad 0.13$
4.36

$\$ 13.40$ 
TABLE 4.12

\section{BROAD WOVENS - FOAM FINISHING}

Basis: Line Speed 100 Yards/Minute

(Raw Materials are the Same as Wet Finishing Same Pickup of Finishing Che micals)

Item

Variable Costs

Direct Labor

(2 persons -

3 shifts)

Supervisory

11/4 person * -

1 shift)

Maintenance

11/2 person* -

1 shift)

Labor Overhead

(40\% of labor)

TOTAL LABOR

Energy

Natural Gas

Electrical Energy

TOTAL ENERGY

TOTAL VARIABLE

\section{Fixed Costs}

Foaming Equipment $110 \%$ of Capital Cost/Year) **

Plant Overhead (60\% of labor costs)

TOTAL FIXED

TOTAL OPERATING COSTS WITHOUT CHEMICALS

\begin{tabular}{|c|c|c|c|}
\hline Units Issed in & & Units Consumed & $\$$ Per 1000 \\
\hline Cost Basis & $\$ /$ Units & of Product & Product \\
\hline
\end{tabular}

Hours

$\$ 11.60$

0.333

$\$ 3.86$

Hours

16.00

0.0139

0.22

Hours

11.60

0.0278

0.32

1.76

6.16

Millions of Btu
Kilowatt hours

6.22

0.147

0.91

$0.066 \quad 1.63$

0.11

$\frac{1.02}{7.18}$

$\$ 375 . /$

$0.000857^{* * *}$

0.32

month

3.70

"Personnel have other duties.

* * $\$ 45,000$ for conversion costs including foamers, controls, horizontal pad rolls, and installation. ** *Based on foaming of 14,000,000 yards per year of fabric.

$\Delta$ Arthur D. Little, Inc. 
TABLE 4.13

\section{BECK DYEING AND CONTINUOUS DRYING OF CARPETS}

Basis: $\quad 2000$ Square Yards/Hour Dyed and Dried

Beck Dyeing and Continuous Drying

(This Capacity Might Require 5 to 10 Beck

Dyers and 1 Dryer)

Raw Material Usage Same as for Foam Dyeing

Item

Variable Costs

Direct Labor

(4 persons -

3 shifts,

1 person on Beck

$\&$ forklift, 2

persons on drier)

Supervisory

$(1 / 2 \text { person })^{*}$

Maintenance

$(1 / 2 \text { person })^{*}$

Labor Overhead

$\{40 \%$ of labor $)$

TOTAL LABOR

\section{Energy}

Fuel for Forklift

Steam

Electrical Energy

TOTAL ENERGY

TOTAL VARIABLE

Fixed Costs

Plant Overhead

$160 \%$ of labor

costs)

TOTAL FIXED

TOTAL OPERATING COSTS

$\begin{array}{cccc}\begin{array}{c}\text { Units Used In } \\ \text { Cost Basis }\end{array} & \text { \$/Unit } & \begin{array}{c}\text { Units Consumed } \\ \text { Per 1000 Yds. } \\ \text { of Product }\end{array} & \begin{array}{c}\$ \text { Per } 1000 \\ \text { Yards of } \\ \text { Product }\end{array} \\ \text { Hours } & \$ 11.60 & 2.00 & \$ 23.20 \\ \text { Hours } & 16.00 & 0.250 & \\ & & & 4.00 \\ \text { Hours } & 11.60 & 0.250 & \\ \text { Hours } & 11.60 & & 12.04\end{array}$

42.14

$\begin{array}{lccr}\text { Millions Btu } & 10.20 & 0.119 & 1.21 \\ \text { Millions Btu } & 5.30 & 11.76 & 62.32 \\ \text { Kilowatt hours } & 0.040 & 180 . & 6.68\end{array}$

112.35

25.28

*Personnel have other duties.

$\triangle$ Arthur D. Little, Inc. 
TABLE 4.14

\section{CONTINUOUS WET DYEING AND DRYING DF CARPETS}

\section{Basis: 2000 Square Yards/Hour}

Continuous Wet Dyeing, Steaming, Washing

and Drying

Raw Materials are the Same as for Foam Dyeing

\section{Item}

Variable Costs

Direct Labor

13 persons -

3 shifts

2 persons on

dryer, 1 person

on forklift

Supervisory

$\{1 / 2 \text { person }\}^{*}$

Maintenance

(1/2 person) $)^{*}$

Labor Overhead

(40\% of labor)

TOTAL LABOR

\section{Energy}

Fuel for Forklift

Steam

Electrical Energy

TOTAL ENERGY

TOTAL VARIABLE

Fixed Costs

Plant Overhead

(60\% of labor costs)

TOTAL FIXED

TOTAL OPERATING COSTS

$\begin{array}{lccc}\begin{array}{c}\text { Units Used in } \\ \text { Cost Basis }\end{array} & \begin{array}{c}\text { Units Consumed } \\ \text { Per 1000 Yds. } \\ \text { of Product }\end{array} & \begin{array}{c}\text { S Per 1000 } \\ \text { Yards of } \\ \text { Product }\end{array} \\ \text { Hours } & \$ 11.60 & 1.5 & \$ 17.40 \\ \text { Hours } & & & \\ \text { Hours } & 16.00 & 0.25 & 4.00 \\ & 11.60 & 0.25 & \\ & & & \\ & & & \\ & & & \end{array}$

$\begin{array}{lrcr}\text { Millions Btu } & \$ 10.20 & 0.101 & 1.03 \\ \text { Millions Btu } & 5.30 & 17.49 & 92.70 \\ \text { Kilowatt hours } & 0.04 & 267 . & 10.68\end{array}$

104.41

138.43

20.41

*Personnel have other duties.

$\triangle$ Arthur D. Little, Inc. 
TABLE 4.15

\section{CONTINUOUS FOAM DYEING AND AIR ORYING OF CARPETS}

Basis: 2000 Square Yards/Hour

Continuous Wet Dyeing, Steaming, and Air Drying

Item

Units Used in

Cost Basis

Units Consumied

\$ Per 1000

Per 1000 Yds. Yards of

s/Unit

of Product

Product

Variable Costs

Direct Labor

Hours

$\$ 11.60$

1.5

$\$ 17.40$

(3 persons -

3 shifts,

2 persons on

equipment, 1

person on forklift)

Supervisory

Hours

16.00

0.25

4.00

(1/2 person $)^{*}$

Maintenance

Hours

11.60

0.25

2.90

(1/2 person) *

Labor Overhead

( $40 \%$ of labor)

TOTAL LABOR

9.72

Energy

Fuel for Forklift

Steam

Millions Btu

10.20

0.101

1.03

Millions Btu

5.30

6.29

33.34

Electrical Energy

Kilowatt hours

0.04

220.

8.80

TOTAL ENERGY

TOTAL VARIABLE

Fixed Costs

Foaming Equipment

(10\% of Capital

Cost/Year) * *

Plant Overhead

(60\% of labor costs)

20.41

TOTAL FIXED

$\$ 1000 / \quad 0.00069 \quad 0.69$

month

43.17

77.19

TOTAL OPERATING COSTS

*Personnel have other duties.

**\$120,000 for conversion costs including foamers, controls and knife-over ro:l.

A Arthur D. Little, Inc. 
TABLE 4.16

ANNUAL OPERATING COST SAVINGS - TUBULAR KNITS

Basis: $5,335,887$ Yards Per Year in Each Finishing Line

\begin{tabular}{lrrr} 
Item & $\begin{array}{c}\text { Conventional } \\
\text { Finishing }\end{array}$ & \multicolumn{1}{c}{$\begin{array}{c}\text { Foam } \\
\text { Finishing }\end{array}$} & $\begin{array}{r}\text { Annual } \\
\text { Savings }\end{array}$ \\
Labor Related Costs & $\$ 189,600$ & $\$ 118,500$ & $\$ 71,100$ \\
Energy Related Costs & 74,600 & 45,700 & 28,900 \\
Fixed Costs & 118,000 & 77,100 & 40,900 \\
Totals & $\$ 382,200$ & $\$ 241,300$ & $\$ 140,900$
\end{tabular}

TABLE 4.17

ANNUAL OPERATING COST SAVINGS BROAD WOVENS*

Basis: $14,000,000$ Yards Finished Per Year

Item
Labor Related Costs
Energy Related Costs
Fixed Costs
Totals

*Harodite

\begin{tabular}{rrr}
$\begin{array}{c}\text { Conventional } \\
\text { Finishing }\end{array}$ & $\begin{array}{c}\text { Foam } \\
\text { Finishing }\end{array}$ & $\begin{array}{r}\text { Annual } \\
\text { Savings }\end{array}$ \\
$\$ 101,400$ & $\$ 86,200$ & $\$ 15,200$ \\
24,800 & 14,300 & 10,500 \\
61,000 & 56,300 & 4,700 \\
\hline$\$ 187,200$ & $\$ 156,800$ & $\$ 30,400$
\end{tabular}


TABLE 4.18

ANNUAL OPERATING COST SAVINGS BECK CARPET DYEING

Basis: $15,840,000$ Square Yards Dyed

\begin{tabular}{|c|c|c|c|}
\hline Item & $\begin{array}{l}\text { Beck } \\
\text { Dyeing }\end{array}$ & $\begin{array}{l}\text { Foam } \\
\text { Dyeing }\end{array}$ & $\begin{array}{l}\text { Annual } \\
\text { Savings }\end{array}$ \\
\hline Labor Related Costs & $\$ 667.500$ & $\$ 538,900$ & $\$ 128,600$ \\
\hline Energy Related Costs & $1,112,000$ & 683,800 & 428,200 \\
\hline Fixed Costs & 400,400 & 343,600 & 56,800 \\
\hline Totals & $\$ 2,179,900$ & $\$ 1,566,300$ & $\$ 613,600$ \\
\hline
\end{tabular}

TABLE 4.19

ANNUAL OPERATING COST SAVINGS CONTINUOUS CARPET DYEING

Basis: $15,840,000$ Square Yards Dyed

Item

Labor Related Costs

Energy Related Costs

Fixed Costs

Totals
Wet

Dyeing

$\$ 538.900$

$1,653,800$

323,300

$\$ 2,516,000$
Foam

Dyeing

$\$ 538,900$ 683,800

343,600

$\$ 1,566,300$
Annual

Savings

$\$ 0$

970.000

$(20,300)$

$\$ 949,700$

$\triangle$ Arthur D. Little, Inc. 
In trying to relate these savings in annual operating costs to the capital investment necessary for retrofitting, we performed a computerized dcf analysis and payback period analysis (shown in Appendix $\mathrm{C}$ ) and found the dcf internal rate of return presented in Table 4.20. The dcf internal rate of return after taxes for the lighter-weight fabrics ranged from 42 to $125 \%$, while the def internal rate of return for the carpets ranged from an outstanding 136 to $140 \%$. If the extra capacity of the finishing line cannot be used, credit can be taken only for the energy savings. In this case, the dcf internal rate of return varied from 14 to $40 \%$ for the lighter-weight fabrics and 130 to $140 \%$ for the carpets. In all cases, the dcf internal rate of return is attractive. The details of the analysis are presented in Appendix C.

TABLE 4.20

\section{SUMMARY OF ECONOMIC INCENTIVES FOR RETROFIT FOAM FINISHING INTO EXISTING PROCESSES}

\begin{tabular}{lcc} 
& \multicolumn{2}{c}{$\begin{array}{c}\text { Discounted Cash Flow-Internal } \\
\text { Rate of Return (\%) }\end{array}$} \\
\cline { 2 - 3 } \multicolumn{1}{c}{ Type of Textile } & $\begin{array}{c}\text { Based on } \\
\text { Total Savings }\end{array}$ & $\begin{array}{c}\text { Based on } \\
\text { Energy Savings Only }\end{array}$ \\
Tubular Knits & 125 & 40 \\
Broad Wovens & 42 & 14 \\
Carpets - Beck & 136 & 130 \\
Carpets - Continuous & 140 & 140
\end{tabular}

To put foam finishing instead of wet finishing into a new mill takes no additional capital investment. All of the operating savings found with the retrofits will accrue to the new plant, and the capital investment will be lower because smaller dryers are needed. Few of the problems normally associated with the introduction of a new technology into any process have been encountered. For example - what effect will foam finishing have on the quality of the finished fabric? The host plants reported excellent finish quality and very low scrap rates. In fact, several other mills, not covered in this audit, have already reported favorable results on the quality of the product with foam finishing. The equipment and knowhow are available from at least five sources:

- United Merchants and Manufacturers, Langley, SC.

- Gaston County Dyeing Machine Company, Mount Holly, NC.

- Textile Rubber and Chemical Co., Dalton, GA.

- Eze, Inc., Dalton, GA.

- Latex Equipment Systems, Inc., Dalton, GA. 
Another question is whether the retrofitting for foam finishing will disrupt production schedules on the finishing lines. At the host plants, the workers installed all equipment during the normal annual shutdown periods for scheduled maintenance. Furthermore, after modification the dryers can still process fabric by wet finishing if any problems should arise in the foam-finishing equipment. The host plants generally finished fabrics successfully on their first trials, however. 


\subsection{CONCLUSIONS AND RECOMMENDATIONS}

The audit confirmed that foam finishing of tubular knits, broad wovens, and carpets is a technically sound and economically attractive process that reduces energy consumption. The host sites retrofitted foam finishing into the existing lines without production upsets and with no adverse effects on quality or scrap rates. The plants were able to add drying capacity to their finishing lines by either increasing the speed of finishing or lowering the temperature of the dryers.

Investments for retrofitting of the foam finishing at the host plant had a dcf internal rate of return varying from 42 to $140 \%$ when energy savings and increased capacity were considered. Even if the extra production capacity could not be used, the retrofitting would have a def internal rate of return varying from 14 to $140 \%$ on energy savings alone. Our analysis indicates that several host plants could realize further energy savings because many of the lighter grades of goods may be dried more than is necessary.

Arthur D. Little believes that the strong economic incentives identified in this study should induce mill managers to adopt foam finishing in all new and existing textile finishing lines. This conversion will occur as managers more fully understand all the technical, energy, and economic benefits of this process.

$\triangle$ Arthur D. Little, Inc. 
. 


\section{APPENDIX A}

\section{HEAT AND WATER BALANCES TO CHECK ACCURACY OF MONITORING EQUIPMENT}





\section{Finish 1457}

Data :

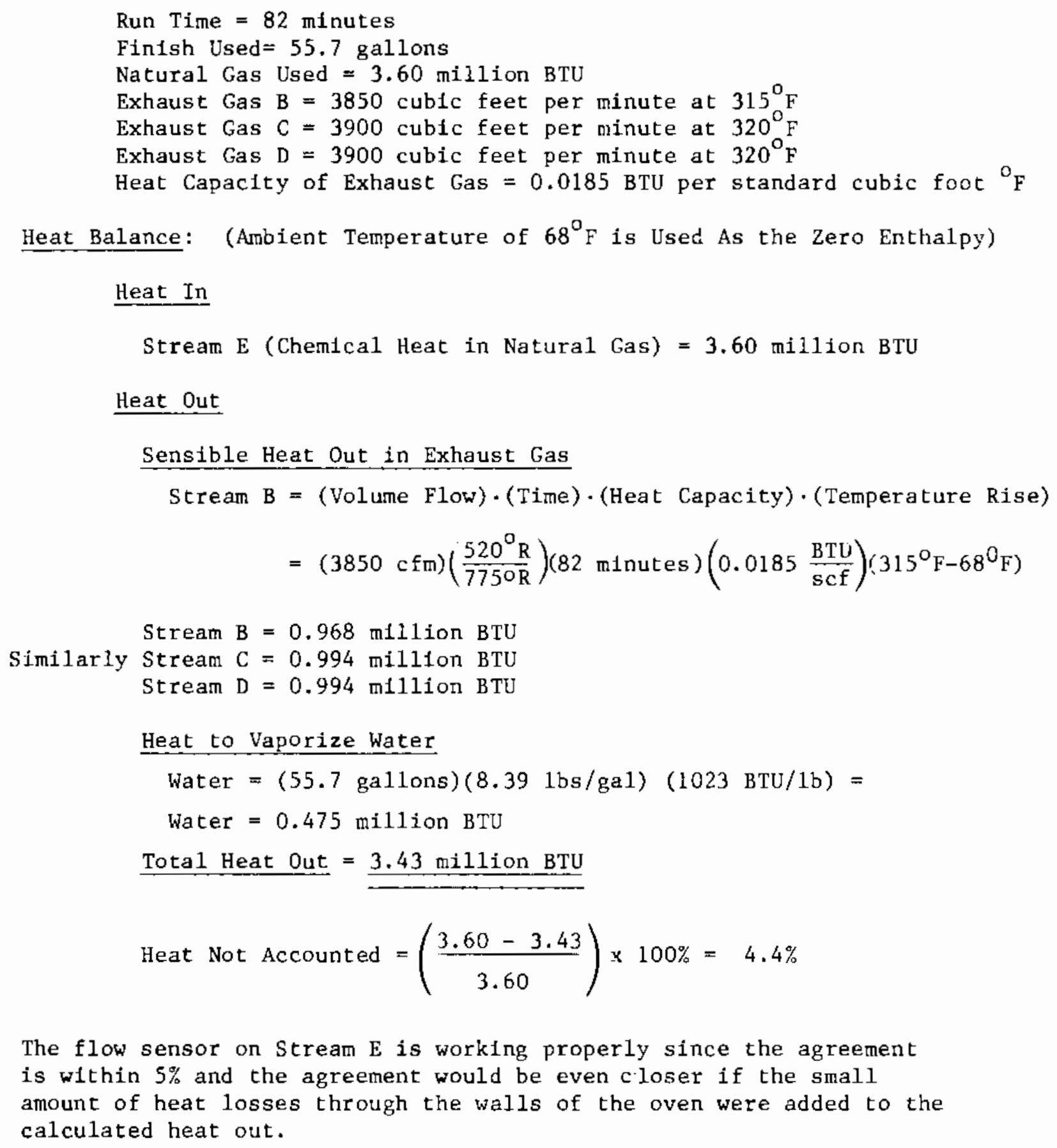

The flow sensor on Stream $\mathrm{E}$ is working properly since the agreement is within 5\% and the agreement would be even closer if the small amount of heat losses through the walls of the oven were added to the calculated heat out.

\section{$\triangle$ Arthur D. Little, Inc.}




\section{Water Balance}

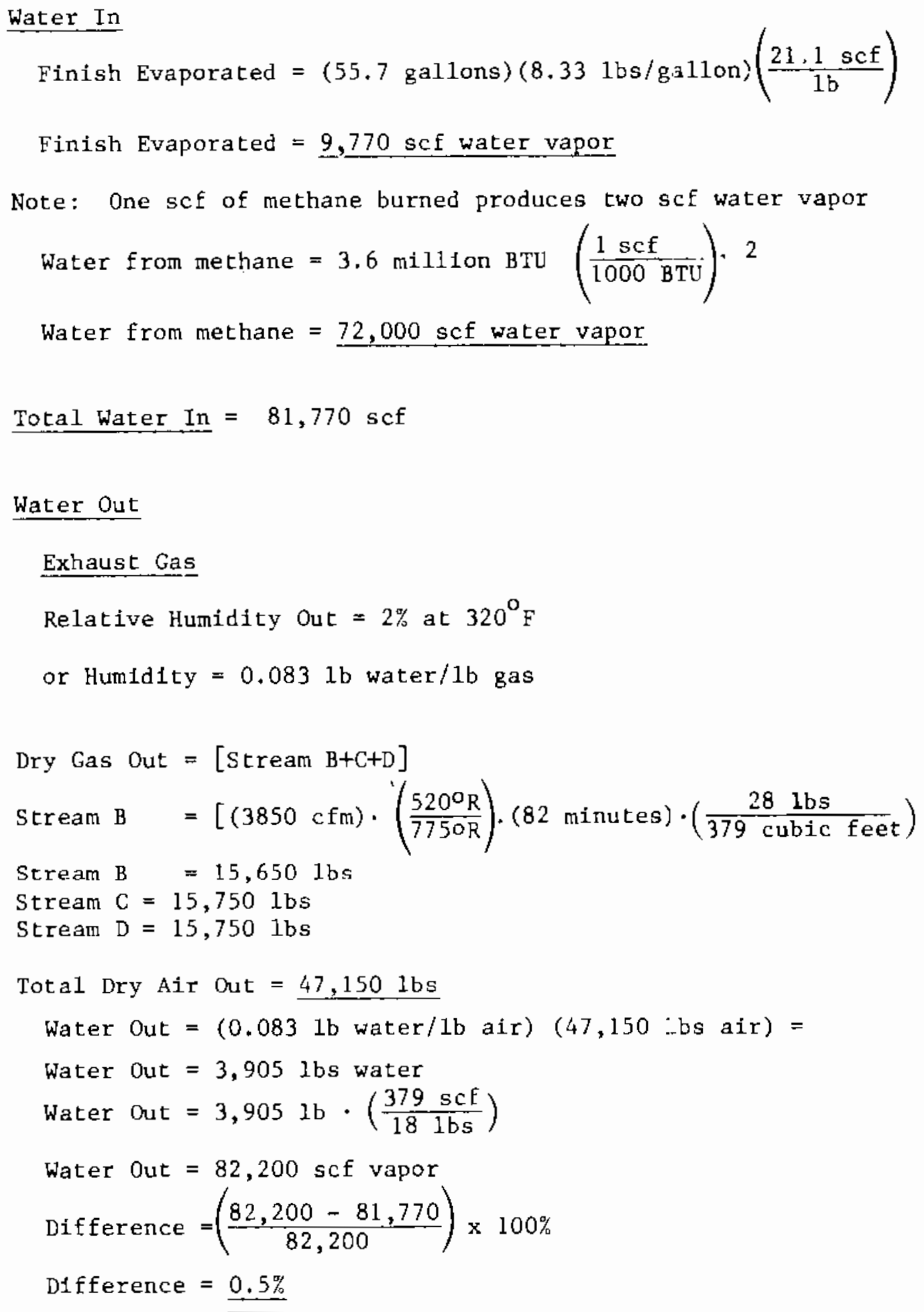

The balance checks well. 


\section{APPENDIX B}

\section{SUMMARIZED DATA}

$\triangle$ Arthur D. Little, Inc. 

WET FINISHING CF TUBULAR KNITS

\begin{tabular}{|c|c|c|c|c|}
\hline Run Number & $\begin{array}{l}\text { Total Yards } \\
\text { Finished }\end{array}$ & $\begin{array}{l}\text { Percent } \\
\text { Water Pickup } \\
\text { After Einishing }\end{array}$ & $\begin{array}{l}\text { Total Energy } \\
\text { Required } \\
\text { Btu/1b }\end{array}$ & $\begin{array}{l}\text { Dryer Efficiency } \\
\text { Percent }\end{array}$ \\
\hline $9-15-81$ & 2024 & 59 & 3391 & 16.9 \\
\hline $9-21-81$ & 439 & 54 & 2990 & 17.5 \\
\hline $9-21-81$ & 1331 & 68 & 3601 & 18.3 \\
\hline $9-22-81$ & 7848 & 52 & 3555 & 14.2 \\
\hline $9-25-81$ & 6565 & 58 & 3597 & 15.6 \\
\hline $9-28-81$ & 2988 & 45 & 3193 & 13.7 \\
\hline $9-28-81$ & 943 & 59 & 3124 & 18.3 \\
\hline $9-29-81$ & 1615 & 67 & 3244 & 20.0 \\
\hline $9-29-81$ & 1789 & 61 & 3421 & 17.3 \\
\hline $10-5-81$ & 4599 & 60 & 3874 & 15.0 \\
\hline $10-5-81$ & 1703 & 61 & 2966 & 19.9 \\
\hline $10-6-81$ & 3411 & 55 & 3461 & 15.4 \\
\hline $10-6-81$ & 1546 & 49 & 3493 & 13.6 \\
\hline $10-6-81$ & 961 & 64 & 3508 & 17.7 \\
\hline $10-7-81$ & 3664 & 68 & 3333 & 19.8 \\
\hline $10-7-81$ & 1122 & 67 & 2973 & 21.9 \\
\hline $10-9-81$ & 854 & 54 & 2818 & 18.6 \\
\hline $10-9-81$ & 3736 & 66 & 3240 & 19.7 \\
\hline $10-9-81$ & 2584 & 66 & 2508 & 25.5 \\
\hline $10-13-81$ & 6927 & 61 & 3083 & 19.2 \\
\hline $10-13-81$ & 1673 & 65 & 4098 & 15.4 \\
\hline $10-14-81$ & 4228 & 60 & 3641 & 16.0 \\
\hline $10-14-81$ & 1545 & 49 & 3174 & 15.0 \\
\hline $10-16-81$ & 3910 & 63 & 2816 & 21.7 \\
\hline $10-16-81$ & 1827 & 63 & 2866 & 21.3 \\
\hline $10-23-81$ & 1265 & 59 & 3744 & 15.3 \\
\hline $10-23-81$ & 1444 & - & 2848 & - \\
\hline $10-23-81$ & 1216 & 58 & 2550 & 22.1 \\
\hline $10-23-81$ & 622 & 56 & 3230 & 16.8 \\
\hline $4-5-82$ & 1499 & 37 & 2400 & 15.0 \\
\hline $4-5-82$ & 1758 & 35 & 2353 & 14.4 \\
\hline $4-6-82$ & 1770 & 38 & 3104 & 11.9 \\
\hline $4-6-82$ & 2083 & 34 & 2874 & 11.5 \\
\hline
\end{tabular}

\section{B-3}




\begin{tabular}{|c|c|c|c|c|}
\hline Run Number & $\begin{array}{l}\text { Total Yards } \\
\text { Finisher }\end{array}$ & $\begin{array}{l}\text { Percent } \\
\text { Water P1ckup } \\
\text { After Finishing }\end{array}$ & $\begin{array}{l}\text { Total Energy } \\
\text { Required } \\
\text { Btu/1is }\end{array}$ & $\begin{array}{l}\text { Dryer Efficiency } \\
\text { Percent }\end{array}$ \\
\hline $4-7-82$ & 2076 & 36 & 3723 & 9.4 \\
\hline $4-7-82$ & 673 & 39 & 3404 & 11.1 \\
\hline $4-7-82$ & 1022 & 30 & 3662 & 7.9 \\
\hline $4-7-82$ & 727 & 36 & 2611 & 13.4 \\
\hline $4-8-82$ & 1362 & 36 & 2991 & 11.7 \\
\hline $4-12-82$ & 4674 & 44 & 2857 & 14.9 \\
\hline $4-12-82$ & 708 & 34 & 2395 & 13.7 \\
\hline $4-13-82$ & 3609 & 38 & 2984 & 12.4 \\
\hline $4-14-82$ & 1773 & 32 & 3562 & 8.7 \\
\hline $4-14-82$ & 1426 & 36 & 3313 & 10.5 \\
\hline $4-15-82$ & 1489 & 44 & 3255 & 13.1 \\
\hline $4-15-82$ & 2536 & 38 & 2938 & 12.5 \\
\hline $4-15-82$ & 757 & 39 & 2360 & 16.0 \\
\hline $4-16-82$ & 1705 & 35 & 3428 & 9.9 \\
\hline $4-16-82$ & 3033 & 33.5 & 3174 & 10.2 \\
\hline $4-16-82$ & 897 & 39 & 2394 & 15.8 \\
\hline $4-20-82$ & 4524 & 40 & 2382 & 16.3 \\
\hline $4-21-82$ & 3109 & 35 & 3303 & 10.3 \\
\hline $4-21-82$ & 761 & 30 & 2587 & 11.2 \\
\hline $4-22-82$ & 2610 & 36 & 3363 & 10.4 \\
\hline $4-22-82$ & 1155 & 42 & 2171 & 18.8 \\
\hline $4-26-82$ & 4963 & 39 & 3331 & 11.4 \\
\hline $4-26-82$ & 3752 & 36 & 2780 & 12.6 \\
\hline $4-27-82$ & 2109 & 36 & 2912 & 12.0 \\
\hline $4-27-82$ & 1173 & 39 & 3379 & 11.2 \\
\hline $4-27-82$ & 3337 & 38 & 2206 & 16.7 \\
\hline $4-28-82$ & 2811 & 35 & 2991 & 11.4 \\
\hline $4-28-82$ & 1788 & 42 & 4070 & 10.0 \\
\hline $4-29-82$ & 1959 & 39 & 2441 & 15.5 \\
\hline $4-29-82$ & 2534 & 38 & 2491 & 14.8 \\
\hline $4-30-82$ & 4198 & 35 & 3269 & 10.4 \\
\hline $4-30-82$ & 1015 & 37 & 3219 & 11.2 \\
\hline
\end{tabular}




\begin{tabular}{|c|c|c|c|c|}
\hline Run Number & $\begin{array}{l}\text { Tutal Yards } \\
\text { Finished }\end{array}$ & $\begin{array}{l}\text { Percent } \\
\text { Warer Pickup } \\
\text { After Finishlng }\end{array}$ & $\begin{array}{l}\text { Total Energy } \\
\text { Requi red } \\
\text { Btu } / 1 \mathrm{~b}\end{array}$ & $\begin{array}{l}\text { Dryer Efficiency } \\
\text { Percent }\end{array}$ \\
\hline $4-30-82$ & 1230 & 39 & 3613 & 10.5 \\
\hline $5-3-82$ & 877 & 36 & 2459 & 14.2 \\
\hline $5-3-82$ & 2961 & 34 & 2436 & 13.5 \\
\hline $5-3-82$ & 1235 & 37 & 2991 & 12.0 \\
\hline $5-4-82$ & 1394 & 38 & 3265 & 11.3 \\
\hline $5-4-82$ & 1833 & 30 & 3391 & 8.6 \\
\hline $5-5-82$ & 2769 & 30 & 3410 & 8.5 \\
\hline $5-5-82$ & 1844 & 37 & 2350 & 15.3 \\
\hline $5-10-82$ & 1586 & 38 & 2579 & 14.3 \\
\hline $5-12-82$ & 2688 & 35 & 2431 & 14.0 \\
\hline $5-14-82$ & 5241 & 36 & 2496 & 14.0 \\
\hline $6-8-82$ & 4762 & 32 & 2976 & 10.4 \\
\hline $6-8-82$ & 4579 & 36 & 2730 & 12.8 \\
\hline $6-10-82$ & 1630 & 57 & 2351 & 23.5 \\
\hline $6-10-82$ & 3512 & 28 & 2582 & 10.5 \\
\hline $6-11-82$ & 1284 & 32 & 2829 & 11.0 \\
\hline $6-11-82$ & 2501 & 54 & 2138 & 24.5 \\
\hline $8-4-82$ & 1880 & 47 & 3530 & 12.9 \\
\hline $8-5-82$ & 1824 & 47 & 2772 & 16.4 \\
\hline $8-5-82$ & 1477 & 50 & 2800 & 17.3 \\
\hline $8-5-82$ & 863 & 46 & 3046 & 14.6 \\
\hline $8-6-82$ & 1589 & 54 & 2702 & 19.4 \\
\hline $8-6-82$ & 5972 & 45 & 2757 & 15.8 \\
\hline $8-10-82$ & 1084 & 50 & 3099 & 15.7 \\
\hline $8-10-82$ & 1223 & - & 3227 & - \\
\hline $8-10-82$ & 4536 & 54 & 2811 & 18.6 \\
\hline $8-12-82$ & 2363 & 57 & 2668 & 20.7 \\
\hline $8-16-82$ & 2589 & 47 & 3660 & 12.5 \\
\hline $8-17-82$ & 6099 & 45 & 3179 & 13.7 \\
\hline $8-18-82$ & 9138 & 40 & 2948 & 13.2 \\
\hline $8-19-82$ & 1484 & 45 & 3901 & 11.2 \\
\hline $8-19-82$ & 5087 & 44 & 3312 & 12.9 \\
\hline $8-20-82$ & 1527 & 50 & 3292 & 14.7 \\
\hline
\end{tabular}

B-5 
WET EINISHING OF TUBULAR KNITS - ContInued

\begin{tabular}{lcccc} 
Run Number & $\begin{array}{l}\text { Total Yards } \\
\text { Finished }\end{array}$ & $\begin{array}{l}\text { Percent } \\
\text { Water Plckup } \\
\text { After Finishing }\end{array}$ & $\begin{array}{l}\text { Total Energy } \\
\text { Required } \\
\text { Btu/1j }\end{array}$ & $\begin{array}{l}\text { Dryer Efficiency } \\
\text { Percent }\end{array}$ \\
\cline { 2 - 3 } $8-20-82$ & 3702 & 52 & 3145 & 16.0 \\
$8-20-82$ & 936 & 43 & $264 \%$ & 15.8 \\
$8-24-82$ & 6295 & 52 & 2627 & 19.2 \\
$8-27-82$ & 1379 & 32 & 2529 & 12.3 \\
$8-27-82$ & 4095 & 50 & 3106 & 15.6 \\
$8-31-82$ & 1153 & 55 & 4150 & 12.9
\end{tabular}


FOAM FINISHING OF TUBULAR KNITS

\begin{tabular}{|c|c|c|c|c|}
\hline Run Number & $\begin{array}{l}\text { Total Yards } \\
\text { Flnished }\end{array}$ & $\begin{array}{l}\text { Percent } \\
\text { Water Plckup } \\
\text { After Finishing }\end{array}$ & $\begin{array}{l}\text { Total Energy } \\
\text { Requitred } \\
\text { Btu/1b }\end{array}$ & $\begin{array}{l}\text { Dryer Efflciency } \\
\text { Percent }\end{array}$ \\
\hline $9-16-81$ & 5491 & 31 & 2067 & 14.5 \\
\hline $9-16-81$ & 1870 & 24 & 1934 & 12.0 \\
\hline $9-16-81$ & 5438 & 29 & 1791 & 15.7 \\
\hline $9-17-81$ & 2065 & 32 & 2037 & 15.2 \\
\hline $9-18-81$ & 2422 & 33 & 1927 & 16.6 \\
\hline $9-18-81$ & 6961 & - & 1841 & - \\
\hline $9-23-81$ & 3998 & - & 2344 & - \\
\hline $9-23-81$ & 4430 & - & 1907 & - \\
\hline $9-24-81$ & 1049 & 43 & 2268 & 34.7 \\
\hline $9-24-81$ & 4510 & - & 1473 & - \\
\hline $9-30-81$ & 5129 & 21 & 2503 & 8.1 \\
\hline $10-1-81$ & 967 & 50 & 3275 & 14.8 \\
\hline $10-1-81$ & 1118 & 45 & 1740 & 25.1 \\
\hline $10-1-81$ & 1442 & 35 & 1738 & 19.5 \\
\hline $10-8-81$ & 1337 & 38 & 1894 & 19.4 \\
\hline $10-8-81$ & 2375 & - & 2053 & - \\
\hline $10-15-81$ & 15094 & 28 & 20.62 & 13.2 \\
\hline $10-19-81$ & 1807 & 43 & 17.02 & 24.5 \\
\hline $10-19-81$ & 1010 & - & 1433 & - \\
\hline $10-19-81$ & 1949 & 19 & 1882 & 9.8 \\
\hline $10-21-81$ & 6386 & 29 & 1953 & 14.4 \\
\hline $10-21-81$ & 1206 & 24 & 1635 & 14.2 \\
\hline $10-22-81$ & 2462 & - & 1985 & - \\
\hline $10-22-81$ & 1333 & 27 & 1971 & 13.2 \\
\hline $10-22-81$ & 1450 & - & 1533 & - \\
\hline $10-26-81$ & 3189 & 29 & 2111 & 13.3 \\
\hline $10-26-81$ & 4350 & 32 & 1572 & 19.8 \\
\hline $10-26-81$ & 445 & 51 & 1308 & 37.9 \\
\hline $10-27-81$ & 1093 & - & 2054 & - \\
\hline $10-27-81$ & 2612 & 23 & 2047 & 10.9 \\
\hline $10-28-81$ & 1217 & 23 & 1550 & 14.4 \\
\hline $10-28-81$ & 2122 & 19 & 2051 & 9.0 \\
\hline $10-28-81$ & 2044 & 49 & 1514 & 31.4 \\
\hline
\end{tabular}

B-7

$\triangle$ Arthur D. Little, Inc. 


\begin{tabular}{|c|c|c|c|c|}
\hline Run Number & $\begin{array}{l}\text { Total Yards } \\
\text { Findshed }\end{array}$ & $\begin{array}{l}\text { Percent } \\
\text { Water Plckup } \\
\text { After Fintsing }\end{array}$ & $\begin{array}{l}\text { Total Energy } \\
\text { Required } \\
\text { Btu/1b }\end{array}$ & $\begin{array}{l}\text { Dryer Efficlency } \\
\text { Percent }\end{array}$ \\
\hline $10-30-81$ & 5578 & 27 & 1911 & 13.7 \\
\hline $10-30-81$ & 4014 & 34 & 2343 & 14.1 \\
\hline $10-30-81$ & 1768 & 26 & 1812 & 13.9 \\
\hline $3-29-82$ & I 205 & 22 & 2491 & 8.5 \\
\hline $3-29-82$ & 1066 & 23 & 2053 & 10.8 \\
\hline $3-29-82$ & 1485 & 35 & 1589 & 21.4 \\
\hline $3-29-82$ & 1048 & 30 & 2160 & 13.5 \\
\hline $3-30-82$ & 4244 & 16 & 1913 & 8.1 \\
\hline $3-30-82$ & 2103 & 17 & 1772 & 9.3 \\
\hline $3-30-82$ & 1170 & 22 & 1692 & 12.6 \\
\hline $3-31-82$ & 1597 & 23 & 1804 & 12.4 \\
\hline $3-31-82$ & 1423 & 21 & 1684 & 12.1 \\
\hline $4-1-82$ & 6330 & 17 & 1470 & 11.2 \\
\hline $4-1-82$ & 2354 & 23 & 2027 & 11.0 \\
\hline $4-1-82$ & 2017 & 19 & 1609 & $1 I .5$ \\
\hline $4-2-82$ & 1019 & 26 & 1708 & 14.8 \\
\hline $4-2-82$ & 1377 & 29 & 1903 & 14.8 \\
\hline $4-2-82$ & 1856 & 15 & 1323 & 11.0 \\
\hline $4-5-82$ & 685 & 20 & 1766 & 11.0 \\
\hline $4-5-82$ & 1451 & 23 & 1946 & 11.5 \\
\hline $4-5-82$ & 879 & 21 & 1823 & 11.2 \\
\hline $4-19-82$ & 6275 & 18 & 2278 & 7.7 \\
\hline $4-23-82$ & 3330 & 25 & 1504 & 16.1 \\
\hline $4-23-82$ & 5057 & 31 & 1739 & 17.3 \\
\hline $4-29-82$ & 3670 & 28 & 1901 & 14.3 \\
\hline $4-30-82$ & 2784 & 26 & 1736 & 14.5 \\
\hline $5-5-82$ & 1056 & 35 & 2029 & 16.7 \\
\hline $5-7-82$ & 1317 & 19 & 1776 & 10.4 \\
\hline $5-7-82$ & 3077 & 23 & 1651 & 13.5 \\
\hline $5-11-82$ & 1855 & 23 & 1621 & 13.7 \\
\hline $5-11-82$ & 2811 & 30 & 1621 & 15.5 \\
\hline $5-12-82$ & 2528 & 36 & 1793 & 19.5 \\
\hline $5-13-82$ & 5258 & 23 & 2155 & 10.4 \\
\hline
\end{tabular}

B-8 


\begin{tabular}{|c|c|c|c|c|}
\hline Run Number & $\begin{array}{l}\text { Total Yards } \\
\text { Flnished }\end{array}$ & $\begin{array}{l}\text { Percent } \\
\text { Water Pickup } \\
\text { After F1nishing }\end{array}$ & $\begin{array}{l}\text { Total Energy } \\
\text { Required } \\
\text { Btu/1b }\end{array}$ & $\begin{array}{l}\text { Dryer Effictency } \\
\text { Percent }\end{array}$ \\
\hline $5-14-82$ & 738 & 19 & 2124 & 8.7 \\
\hline $5-17-82$ & 1348 & 20 & 1609 & 12.1 \\
\hline $5-17$ to $19-82$ & $2282 / 11997 / 1307$ & $26 / 22 / 20$ & $1859 / 1601 / 1871$ & $33.6 / 13.3 / 10.4$ \\
\hline $5-21-82$ & 1809 & 35 & 1820 & 18.7 \\
\hline $5-21-82$ & 240 & 23 & 1678 & 13.1 \\
\hline $5-21-82$ & 921 & 18 & 1899 & 9.2 \\
\hline $5-25-82$ & 2491 & 23 & 1443 & 15.4 \\
\hline $5-25-82$ & 2824 & 19 & 2094 & 8.8 \\
\hline $5-25-82$ & 3884 & 20 & 1722 & 11.3 \\
\hline $5-27-82$ & 1789 & 24 & 1650 & 14.1 \\
\hline $5-27-82$ & 4271 & 18 & 1922 & 9.1 \\
\hline $6-1-82$ & 3722 & 31 & 1622 & 12.0 \\
\hline $6-3-82$ & 2839 & 29 & 1927 & 14.6 \\
\hline $6-4-82$ & 1958 & 17 & 2214 & 7.5 \\
\hline $6-7-82$ & 1918 & 27 & 1653 & 15.8 \\
\hline $6-7-82$ & 1800 & 35 & 1797 & 18.9 \\
\hline $6-7-82$ & 3276 & 24 & 1876 & 12.4 \\
\hline $6-7-82$ & 1350 & 22 & 1836 & 11.6 \\
\hline $6-9-82$ & 6812 & 32 & 1590 & 19.5 \\
\hline $6-15-82$ & 3234 & 22 & 1801 & 11.8 \\
\hline $7-29-82$ & 1859 & 23 & 1515 & 14.7 \\
\hline $7-29-82$ & 2041 & 19 & 1542 & 11.9 \\
\hline $7-29-82$ & 4040 & 18 & 1788 & 9.8 \\
\hline $7-30-82$ & 5675 & 19 & 2089 & 8.8 \\
\hline $7-30-82$ & 732 & 20 & 1395 & 13.9 \\
\hline $7-30-82$ & 4151 & 18 & 1904 & 9.2 \\
\hline $8-2-82$ & 3967 & 29 & 1696 & 16.6 \\
\hline $8-2-82$ & 2745 & 27 & 1911 & 13.7 \\
\hline $8-2-82$ & 1849 & 20 & 1484 & 13.1 \\
\hline $8-2-82$ & 1103 & 24 & 1434 & 16.2 \\
\hline $8-3-82$ & 1894 & 22 & 1819 & 11.7 \\
\hline $8-3-82$ & 1609 & 19 & 1900 & 9.7 \\
\hline $8-4-82$ & 2527 & 23 & 1629 & 13.7 \\
\hline
\end{tabular}

B-9 


\begin{tabular}{lcccc} 
Run Number & $\begin{array}{l}\text { Total Yards } \\
\text { Finished }\end{array}$ & $\begin{array}{l}\text { Percent } \\
\text { Water Plckup } \\
\text { After Finishing }\end{array}$ & $\begin{array}{l}\text { Total. Energy } \\
\text { Required } \\
\text { Btu/1b }\end{array}$ & $\begin{array}{c}\text { Dryer Efficiency } \\
\text { Percent }\end{array}$ \\
\cline { 2 - 3 } $8-13-82$ & 11496 & 22 & 1934 & 11.0 \\
$8-23-82$ & 4692 & 16 & 1813 & 8.6 \\
$8-23-82$ & 1841 & 22 & 1445 & 14.8 \\
$8-23-82$ & 5044 & 23 & 1866 & 12.0 \\
$8-25-82$ & 2658 & 27 & 2215 & 14.3 \\
$8-25-82$ & 7786 & 26 & 1628 & 15.5 \\
$8-26-82$ & 4822 & - & 2026 & - \\
$8-30-82$ & 6726 & 58 & 1751 & 32.1 \\
$8-30-82$ & 3077 & 33 & 1861 & 17.2 \\
$9-1-82$ & 6432 & 26 & 1902 & 13.3 \\
$9-2-82$ & 2651 & 45 & 1731 & 25.2
\end{tabular}


WET FINISHING OF BROAD WOVEN GOODS

\begin{tabular}{|c|c|c|c|c|}
\hline Run Number & $\begin{array}{l}\text { Total Yards } \\
\text { Einished }\end{array}$ & $\begin{array}{l}\text { Percent } \\
\text { Water Pickup } \\
\text { After Finishing }\end{array}$ & $\begin{array}{l}\text { Total Energy } \\
\text { Required } \\
\text { Btu/1b }\end{array}$ & $\begin{array}{l}\text { Dryer Efflctency } \\
\text { Percent }\end{array}$ \\
\hline $9-28-81$ & 6300 & 81 & 880.4 & 81 \\
\hline $10-5-81$ & 4790 & 89.2 & 1969.4 & 39 \\
\hline $2-23-82$ & 7644 & 72 & 794.2 & 78 \\
\hline - & 7930 & 66 & 857.3 & 65 \\
\hline $2-23-82$ & 8115 & 75 & 865.5 & 74 \\
\hline $2-23-82$ & 3085 & 77 & 883.2 & 75 \\
\hline $2-23-82$ & 21140 & 76 & 824.3 & 79 \\
\hline $2-23-82$ & 2856 & 79 & 855.0 & 80 \\
\hline $2-23-82$ & 5450 & 72 & 853.5 & 72 \\
\hline $2-23-82$ & 9820 & 75 & 682.6 & 96 \\
\hline $4-5-82$ & 10560 & 82 & 748.9 & 103 \\
\hline $4-5-82$ & 5515 & 77 & 746.0 & 90 \\
\hline $4-5-82$ & 20095 & 72 & 844.8 & 75 \\
\hline $4-5-82$ & 3400 & 74 & 703.3 & 94 \\
\hline $4-6-82$ & 13000 & 74 & 790.0 & 82 \\
\hline $8-19-82$ & 6950 & 85.7 & 352.0 & - \\
\hline $9-28-81$ & 8500 & 38 & 489.1 & - \\
\hline $10-15-81$ & 19200 & 33.9 & 420.9 & 65 \\
\hline $10-15-81$ & 3325 & 25 & 456.8 & 42 \\
\hline $1-12-81$ & 6120 & 38 & 2050.3 & 17 \\
\hline $2-1-82$ & 9250 & 37.8 & 855.5 & 26 \\
\hline $2-8-82$ & 7560 & 38.5 & 813.3 & 37 \\
\hline $2-8-82$ & 7300 & 37.1 & 808.3 & 35 \\
\hline
\end{tabular}

B-11 


\begin{tabular}{|c|c|c|c|c|}
\hline Run Number & $\begin{array}{l}\text { Total Yards } \\
\text { Finlshed }\end{array}$ & $\begin{array}{l}\text { Percent } \\
\text { Water Pickup } \\
\text { After Finishing }\end{array}$ & $\begin{array}{l}\text { Tota: Energy } \\
\text { Requi.red } \\
\text { Btu/lb }\end{array}$ & $\begin{array}{l}\text { Dryer Efficiency } \\
\text { Percent }\end{array}$ \\
\hline $2-8-82$ & 5035 & 36.7 & 743.6 & 39 \\
\hline $2-8-82$ & 13470 & 39.1 & 799.0 & 36.0 \\
\hline $2-8-82$ & 10350 & 36.1 & 793.7 & 34.0 \\
\hline $2-9-82$ & 2273 & 31.0 & 775.0 & 30.41 \\
\hline $2-9-82$ & 4480 & 38.4 & 935.2 & 32.25 \\
\hline $2-16-82$ & 9359 & 35.8 & 613.3 & 45.86 \\
\hline $2-16-82$ & 7610 & 42.7 & 601.1 & 57.14 \\
\hline $2-17-82$ & 10000 & 39.7 & 803.5 & 39.33 \\
\hline $3-30-82$ & 5200 & 34.0 & 375.4 & 68.0 \\
\hline $9-7-82$ & 7150 & 37.2 & 93 & - \\
\hline $9-7-82$ & 3050 & 35.4 & 104 & - \\
\hline $9-7-82$ & 7375 & 39 & 83 & - \\
\hline $9-13-82$ & 6400 & 38 & 71 & - \\
\hline $9-13-82$ & 4400 & 34 & 97 & - \\
\hline
\end{tabular}




Run Number
$1-25-82$
$1-25-82$
$1-25-82$
$1-25-82$
$1-25-82$
$1-25-82$
$1-25-82$
$1-25-82$
$1-25-82$
$1-25-82$
$1-27-82$
$1-27-82$
$1-27-82$
$1-27-82$
$1-27-82$
$1-27-82$

Pounds Dyed

1380

1340

1600

1360

1410

1650

1400

1100

5160

5770

1380

2150

1750

1550

1710

1360
Total Energy

Required Btu/1b

4143

1075

1252

5954

3960

4933

5505

7385

780

1271

6151

3227

835

826

4326

5151

\section{B-13}

$\Delta$ Arthur D. Little, Inc. 
WET CONTINUOUS DYEING AND STEAMING OF CARPETS

\begin{tabular}{lcc}
$\begin{array}{l}\text { Run } \\
\text { Number }\end{array}$ & $\begin{array}{l}\text { Total Pounds } \\
\text { Dyed }\end{array}$ & \multicolumn{1}{c}{$\begin{array}{c}\text { Total Energy } \\
\text { Btu/1b }\end{array}$} \\
$6-28-82$ & 4,086 & 6692.5 \\
$6-29-82$ & 66,934 & 7734.1 \\
$7-12-82$ & 19,814 & $23,219.0$ \\
$7-13-82$ & 54,995 & 8271.2 \\
$7-14-82$ & 22,513 & 9418.3 \\
$7-15-82$ & 50,108 & 7127.0 \\
$7-16-82$ & 69,639 & 8109.7 \\
$7-19-82$ & 41,826 & 8756.2 \\
$7-20-82$ & 55,028 & 9617.2 \\
$7-21-82$ & 61,062 & 4882.2 \\
$7-22-82$ & 117,450 & 5700.2 \\
$7-23-82$ & 100,186 & 5271.2 \\
$7-26-82$ & 76,287 & 8266.2 \\
$7-27-82$ & 85,128 & 6432.2 \\
$7-28-82$ & 105,917 & 4916.2
\end{tabular}


FOAM DYEING AND STEAMING OF CARPETS

\begin{tabular}{lcc} 
Run Number & $\begin{array}{l}\text { Total Pounds } \\
\text { Dyed }\end{array}$ & $\begin{array}{l}\text { Total Energy } \\
\text { Btu/1b }\end{array}$ \\
\cline { 2 - 3 } $7-21-82$ & 3498 & $13,450.8$ \\
$7-21-82$ & 3623 & $14,050.8$ \\
$7-21-82$ & 8775 & $22,037.0$ \\
$7-26-82$ & 4231 & $3,239.3$ \\
$7-26-82$ & 4620 & $3,867.4$
\end{tabular}

B- 15

$\Lambda$ Arthur D. Little, Inc. 
Run Number

5-20-82

5-21-82

5-24-82

5-25-82

5-26-82

$5-27-82$

$5-27 / 28-82$

5-28-82

6-1-82

$6 \div 1 / 2-82$

6-4-82

6-7-82

$6-7 / 8-82$

$6-8-82$

$6-3 / 9-82$

6-9-82

$6-9 / 10-82$

$6-10-82$

$6-10 / 11-82$

6-11-82
Total Pounds Dried

$23,675.20$

$56,865.74$

$35,059.99$

$45,775.77$

$58,468.28$

$48,497.00$

$61,525.83$

$24,339.17$

$28,660.96$

$68,236.06$

$33,083.64$

$28,154.56$

$53,526.43$

$66,726.56$

$98,207.25$

$46,506.92$

$106,767.83$

$54,259.79$

$134,900.95$

$64,973.26$
Total Energy Requlred Btu/Lb

3004

1627.55

1786.47

1689.69

1329.23

1583.72

1814.14

1841.96

1860.49

1928.52

1732.73

1799.11

1665.66

1419.28

1475.44

1504.62

1433.82

1653.11

1362.84

1410.5

B-16 


\section{APPENDIX C \\ RESULTS OF COMPUTERIZED PAYBACK-PERIOD CALCULATIONS}

A Arthur D. Little, Inc. 



\section{Table $\mathrm{C}-1$ \\ SLMMKY OF ECONOMIC 1NCENTIVES \\ FOR RETROFIT FOAM FINISHING INTO \\ EXISTING PROCESS WITH CONSTANT DOLLARS}

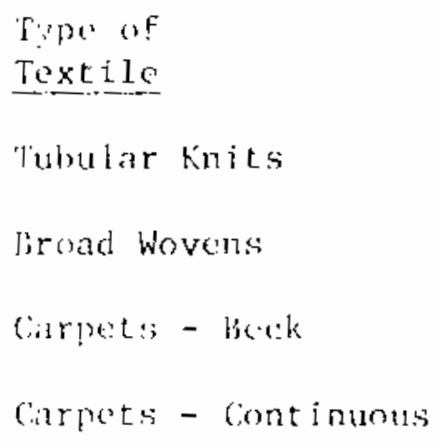

0.5 yearts

0.4 years

Total Savings

0.8 vears

2.3 years

0.7 ycars

0.4 years 
Table $\mathrm{C}-2$

SUMMARY OF ECONOMIC INCENTIVES

FOR RETROFIT FOAM FINISHING INTO

EXISTING PROCESSES WITH $5 \%$ INFLATION

Type of

Textile

Tubular knfts

Broad Wovens

Carpets - Beck

Carpets - Continuous
Payback Perlod for Capital Investment - Years

Based on

Based on Energy

Total Savings

Savings Only

0.8 vears

2.4 years

2.3 years

4.2 years

0.5 years

0.7 years

0.4 years 


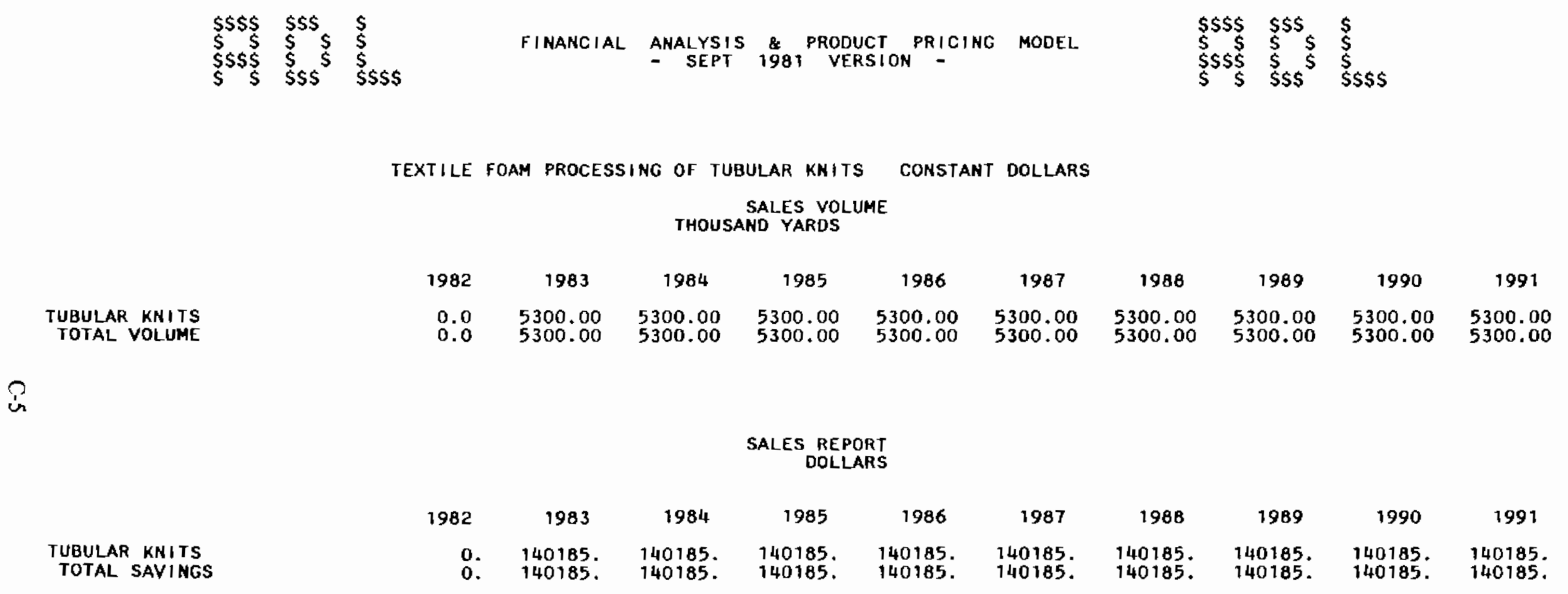




\section{TEXTILE FOAM PROCESSING OF TUBULAR KNITS CONSTANT DOLLARS}

INCOME STATEMENT

DOLLARS

\begin{tabular}{|c|c|c|c|c|c|c|c|c|c|c|}
\hline & 1982 & 1983 & 1984 & 1985 & 1986 & 1987 & 1988 & 1989 & 1990 & 1991 \\
\hline $\begin{array}{l}\text { NET SAVIMGS } \\
\text { BOOK DEPRECIATION } \\
\text { OPERATING PROFIT } \\
\text { INTEREST INCOME } \\
\text { INTEREST EXPENSE } \\
\text { PROF IT BEFORE TAX } \\
\text { TAX EXPENSE } \\
\text { PROF IT AFTER TAX }\end{array}$ & $\begin{array}{l}0 . \\
0 . \\
0 . \\
0 . \\
0 . \\
0 . \\
0 . \\
0 .\end{array}$ & $\begin{array}{r}140185 \\
4500 \\
135685 \\
0 \\
37 \\
135648 \\
57898 \\
77750\end{array}$ & $\begin{array}{r}140185 \\
4500 \\
135685 \\
344 \\
37 \\
135993 \\
62557 \\
73436\end{array}$ & $\begin{array}{r}140185 \\
4500 \\
135685 \\
1021 \\
0 \\
136706 \\
62885 \\
73821 .\end{array}$ & $\begin{array}{r}140185 . \\
4500 \\
135685 \\
1684 . \\
0 \\
137369 \\
63190 \\
74179 .\end{array}$ & $\begin{array}{r}140185 . \\
4500 \\
135685 \\
2347 \\
0 . \\
138032 . \\
63495 \\
74537 .\end{array}$ & $\begin{array}{r}140185 . \\
4500 . \\
135685 \\
2844 . \\
0 . \\
138529 \\
63723 . \\
74806 .\end{array}$ & $\begin{array}{r}140185 . \\
4500 . \\
135685 . \\
3132 . \\
0 . \\
138817 . \\
63856 . \\
74961 .\end{array}$ & $\begin{array}{r}140185 . \\
4500 . \\
135685 . \\
3377 . \\
0 . \\
139062 . \\
63969 . \\
75094 .\end{array}$ & $\begin{array}{r}140185 \\
4500 \\
135685 \\
3623 \\
0 \\
139308 \\
64081 \\
75226\end{array}$ \\
\hline
\end{tabular}

Q FOR TAX PURPOSE

DEPRECIATION

TAXABLE INCOME

INCOME TAXES

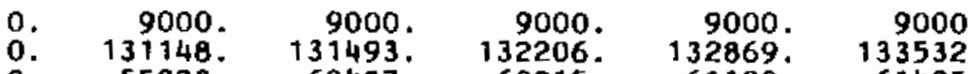

61120 .

61425 .

143029.

.

143317. 143562.0140. 65793. 65926. $66039^{\circ} .66151$.

INVESTMENT CREDIT USED

o. 4500 .

0 .

0.

0.

0.

o.

0.

0 .

0.

RETURN ON GROSS ASSETS

RETURN ON NET HORTH

RETURH OH NET OPERAT. ASSETS

\section{$0.0 \quad i 24.9 \quad 88$.}

$88.5 \quad 82.2$

$\begin{array}{rrrr}120.0 & 120.6 & 76.9 & 72.3\end{array}$

$100.6 \quad 107.3$

114.8

121.8

69.3
122.2

122.2

\section{6}

$\begin{array}{rr}66.3 & 65.0\end{array}$

PAT = PROFIT AFTER TAXES

ROGA = PAT (ADJUSTEO FOR INTEREST EXPENSE) / AVERAGE BALANCE OF CURRENT ASSETS AND GROSS PLANT + EQUIPMENT

RONH = PAT / AVERAGE NET HORTH

RONA = PAT (ADJUSTED FOR INTEREST INCOME AND EXPENSE) / AVERAGE BALANCE OF NET FIXED ASSETS AND OPERATING HORKING

CAPITAL (1.E.: CASH+RECE IVABLES+INVENTORIES+OTHER-PAYABLES) 


\begin{tabular}{|c|c|c|c|c|c|c|c|c|c|c|}
\hline 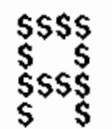 & 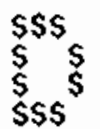 & 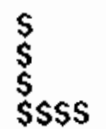 & FI NANCIAL & $\begin{array}{l}\text { ANALYSIS } \\
-\quad \text { SEPT }\end{array}$ & $\stackrel{8}{1981}$ & $\begin{array}{l}\text { PRODUCT } \\
\text { VERSION }\end{array}$ & PRICING & MODEL & $\begin{array}{l}\text { \$\$\$\$ } \\
\text { S\$\$ } \\
\text { \$\$SS } \\
\text { S }\end{array}$ & 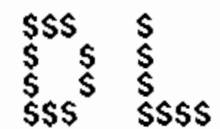 \\
\hline
\end{tabular}

TEXTILE FOAM PROCESSING OF TUBULAR KNITS ENERGY ONLY

SALES VOLUME

THOUSAND YAROS

TUBULAR KNITS

TOTAL VOLUME

$?$

TUBULAR KMITS TOTAL SAVINGS
1982

$\begin{array}{lllll}0.0 & 5300.00 & 5300.00 & 5300.00 & 5300.00\end{array}$

1987

5300.00

1988

1989

1990

1991

$5300.00 \quad 5300.00$

$300.00 \quad 5300.00$

5300.00

$5300.00 \quad 5300.00$

5300.00

5300.00

5300.00
SALES REPORT

DOLLARS

$\begin{array}{rrrrrrrrrr}1982 & 1983 & 1984 & 1985 & 1986 & 1987 & 1988 & 1989 & 1990 & 1991 \\ 0 . & 28673 . & 28673 . & 28673 . & 28673 . & 28673 . & 28673 . & 28673 . & 28673 . & 28673 . \\ 0 . & 28673 . & 28673 . & 28673 . & 28673 . & 28673 . & 28673 . & 28673 . & 28673 . & 28673 .\end{array}$




\section{TEXTILE FOAM PROCESSING OF TUBULAR KNITS ENERGY ONLY}

I NCOME STATEMENT

DOLLARS

\begin{tabular}{|c|c|c|c|c|c|c|c|c|c|}
\hline & 1982 & 1983 & 1984 & 1985 & 1986 & 1987 & 1988 & 1989 & 1990 \\
\hline $\begin{array}{l}\text { IET SAVINGS } \\
\text { BOOK DEPRECIIATION } \\
\text { PERATING PROFIT } \\
\text { INTEREST INCOME } \\
\text { INTEREST EXPENSE } \\
\text { ROFIT BEFORE TAX } \\
\text { TAX EXPENSE } \\
\text { ROFIT AFTER TAX }\end{array}$ & $\begin{array}{l}0 . \\
0 . \\
0 . \\
0 . \\
0 . \\
0 . \\
0 . \\
0 .\end{array}$ & $\begin{array}{r}28673 . \\
4500 . \\
24173 . \\
21 . \\
0 . \\
24194 . \\
6629 . \\
17565 .\end{array}$ & $\begin{array}{r}28673 . \\
4500 . \\
24173 . \\
417 . \\
0 . \\
24590 . \\
11311 . \\
13278 .\end{array}$ & $\begin{array}{r}28673 \\
4500 \\
24173 \\
1124 \\
0 . \\
25297 \\
11636 \\
13660\end{array}$ & $\begin{array}{r}28673 . \\
4500 . \\
24173 \\
1787 \\
0 . \\
25960 . \\
11942 . \\
14018 .\end{array}$ & $\begin{array}{r}28673 \\
4500 \\
24173 \\
2450 \\
0 \\
26623 \\
12247 \\
14376\end{array}$ & $\begin{array}{r}28673 . \\
4500 \\
24173 \\
2947 \\
0 . \\
27120 \\
12475 \\
14645\end{array}$ & $\begin{array}{r}28673 . \\
4500 \\
24773 . \\
3235 \\
0 . \\
27408 . \\
12608 . \\
14800 .\end{array}$ & $\begin{array}{r}28673 . \\
4500 . \\
24173 . \\
3480 . \\
0 . \\
27653 . \\
12721 . \\
14933 .\end{array}$ \\
\hline
\end{tabular}

$\infty$

FOR TAX PURPOSE

DEPRECIATION

TAXABLE INCOME

INCOME TAXES

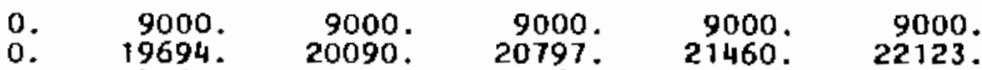

14800 .

14933 . 15065

INVESTMENT CREOIT USED

(BOOK AND TAX)

0. 4500 .

9241.

9566.

9872 .

10177.

37620 .

14545 .

37908

0.

32153.

14791.

32399

14903 .

0.

0 .

0 .

0.

0.

0

0 .

0 .

\section{RETURN ON GROSS ASSETS}

RETURN ON NET HORTH

RETURN ON NET OPERAT. ASSETS

\section{$0.0 \quad 36.0$}

$\begin{array}{ll}0.0 & 39.0 \\ 0.0 & 37.9\end{array}$

23.6
29.5
28.8

21.6
30.4
32.0

20.0
31.2
35.9

18.8
31.9

18.0
32.5

17.5
32.9
57.2

17.2
33.2

71.3

16.9
33.5

PAT = PROFIT AFTER TAXES RONW = PAT, AVERAGE NET HORTH

RONA = PAT (ADJUSTED FOR INTEREST INCOME AND EXPENSE) / AVERAGE BALANCE OF NET FIXED ASSETS AND OPERATING HORKING CAPITAL (1,E.:CASH+RECE IVABLES+ INVENTORIES+OTHER-PAYABLES)

* *QUUITY PAYBACK PERIOD**

AFTER END OF CONSTRUCTION 


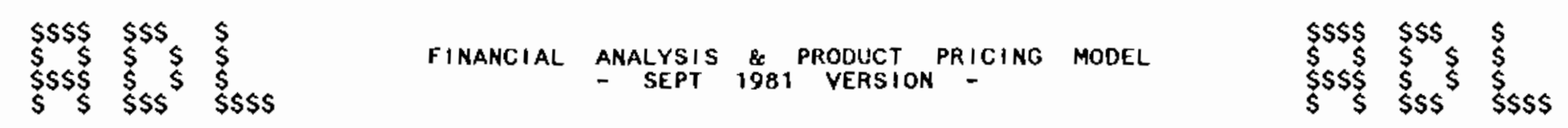

TEXTILE FOAM PROCESSING OF BROAD WOVENS IN CONSTANT DOLLARS

\section{SALES VOLUME
THOUSANU YARDS}

BROAD WOVENS

TOTAL VOLUME

?

\begin{tabular}{|c|c|c|c|c|c|c|c|c|c|c|}
\hline & & & & $\begin{array}{l}\text { QLES RE } \\
\text { DOL }\end{array}$ & & & & & & \\
\hline & 1982 & 1983 & 1984 & 1985 & 1986 & 1987 & 1988 & 1989 & 1990 & 1991 \\
\hline $\begin{array}{l}\text { BROAD WOVENS } \\
\text { TOTAL SAYINGS }\end{array}$ & $\begin{array}{l}0 . \\
0 .\end{array}$ & $\begin{array}{l}30800 . \\
30800 .\end{array}$ & $\begin{array}{l}30800 \\
30800\end{array}$ & $\begin{array}{l}30800 \\
30800 .\end{array}$ & $\begin{array}{l}30800 . \\
30800 .\end{array}$ & $\begin{array}{l}30800 \\
30800\end{array}$ & $\begin{array}{l}30800 . \\
30800 .\end{array}$ & $\begin{array}{l}30800 \\
30800\end{array}$ & $\begin{array}{l}30800 \\
30800\end{array}$ & $\begin{array}{l}30000 . \\
30800 .\end{array}$ \\
\hline
\end{tabular}


TEXTILE FOAM PROCESSING OF BROAD HOVENS IN CONSTANT DOLLARS

$$
\begin{aligned}
& \text { INCOME STATEMENT } \\
& \text { DOLLARS }
\end{aligned}
$$

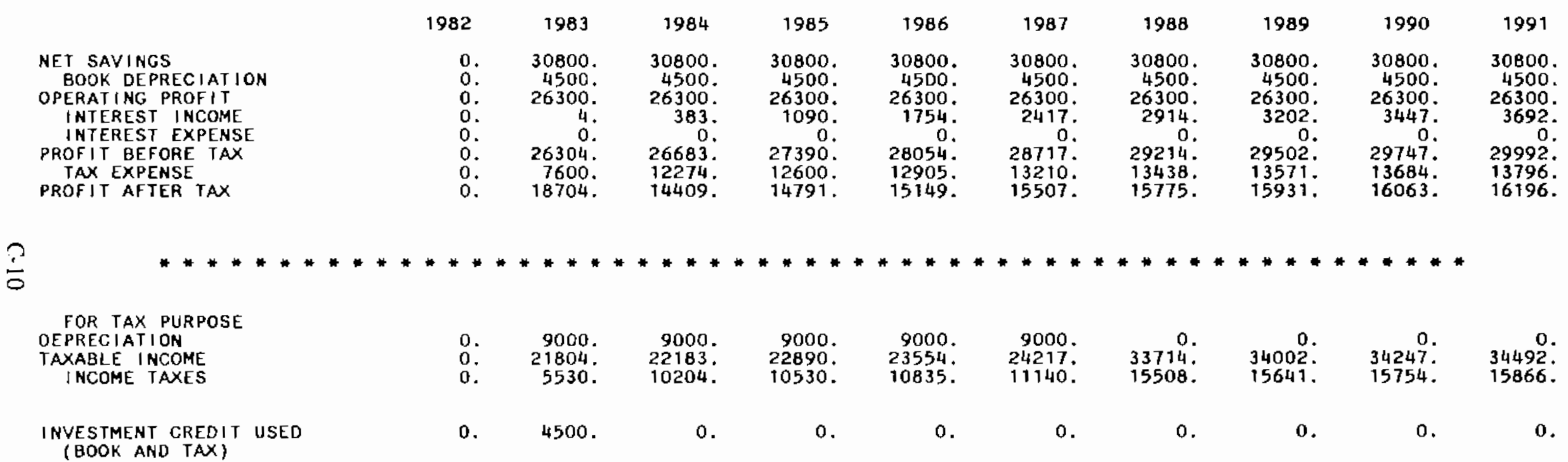

RETURN ON GROSS ASSETS

RETURN ON NET WORTH

RETURN ON NET OPERAT. ASSETS

\section{$\begin{array}{llll}0.0 & 38.3 & 25.5 & 23.3 \\ 0.0 & 41.6 & 32.0 & 32.9\end{array}$}

21.6

20.2

19.3
35.1

18.8

18.4
35.7

18.1

PAT = PROFIT AFTER TAXES

ROGA = PAT (ADJUSTED FOR INTEREST EXPENSE) / AVERAGE BALANCE OF GURRENT ASSETS AND GROSS PLANT + EQUIPMENT

RONH = PAT AVERAGE NET WORTH

RONA = PAT (ADJUSTED FOR INTEREST INCOME AND EXPENSE) / AVERAGE BALANCE OF NET FIXED ASSETS AND OPERATING HORKING

$\begin{aligned} & \text { RONA }= \text { PAT (ADJUSTED FOR INTEREST INCOME AND EXPENSE) / AVERAGE BAL } \\ & \text { CAPITAL ( } 1 . E .: \text { CASH+RECEIVABLES+INVENTORIES+OTHER-PAYABLES) }\end{aligned}$ 


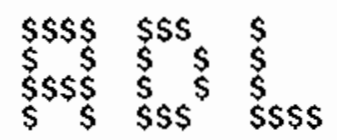

$\begin{array}{cccc}\text { FINANCIAL ANALYSIS } & \& \\ & - & \text { PROPT } & 1981 \text { VERSION PRICING MOOEL }\end{array}$

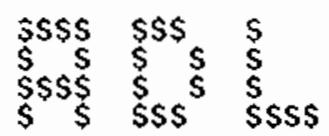

TEXTILE FOAM PROCESSING OF BROAD HOVENS

ENERGY ONLY

GROAD WOVENS

TOTAL VOLUME SALES VOLUME
THOUSAND YARDS

$\begin{array}{rrrrrrrrrr}1982 & 1983 & 1984 & 1985 & 1986 & 1987 & 1988 & 1989 & 1990 & 1991 \\ 0.0 & 14000.00 & 14000.00 & 14000.00 & 14000.00 & 14000.00 & 14000.00 & 14000.00 & 14000.00 & 14000.00 \\ 0.0 & 14000.00 & 14000.00 & 14000.00 & 14000.00 & 14000.00 & 14000.00 & 14000.00 & 14000.00 & 14000.00\end{array}$

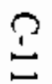

SALES REPORT

$\begin{array}{llllllllll}1982 & 1983 & 1984 & 1985 & 1986 & 1987 & 1988 & 1989 & 1990 & 1991\end{array}$

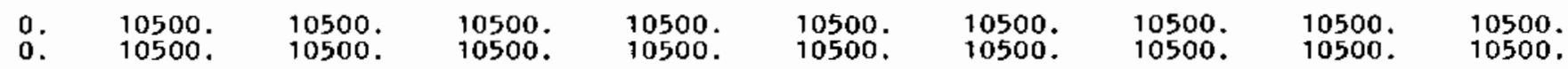


TEXTILE FOAM PROCESSING OF BROAD HOVENS ENERGY ONLY

I NCOME STATEMENT
OOLLARS

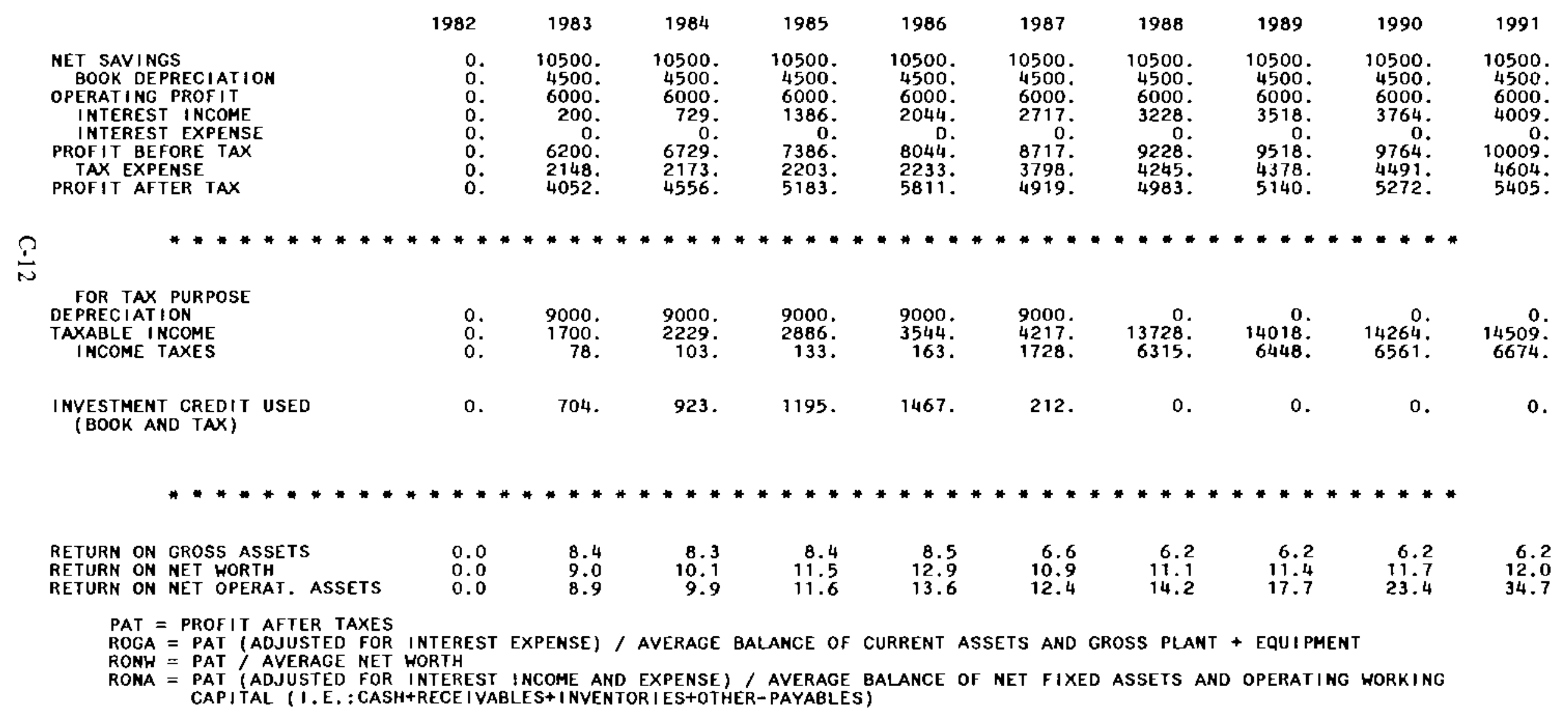

**Equ ITY PAYBACK PERIOD**

AFTER END OF CONSTRUCTION 


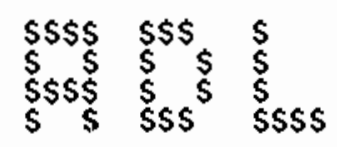

FINANCIAL ANALYSIS $\&$ PRODUCT PRICING MODEL

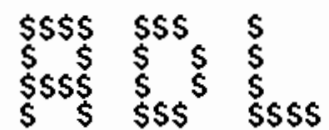

TEXTILE FOAH DYEING OF CARPETS, BECK DYEING AS A BASE

\section{CARPETS \\ TOTAL VOLUME}

$\stackrel{?}{\omega}$

CARPETS

TOTAL SAVIMGS
SALES VOLUME
THOUSAND YARDS

$\begin{array}{rrrrrrrrrr}1982 & 1983 & 1984 & 1985 & 1986 & 1987 & 1988 & 1989 & 1990 & 1991 \\ 0.0 & 15840.00 & 15840.00 & 15840.00 & 15840.00 & 15840.00 & 15840.00 & 15840.00 & 15840.00 & 15840.00 \\ 0.0 & 15840.00 & 15840.00 & 15840.00 & 15840.00 & 15840.00 & 15840.00 & 15840.00 & 15840.00 & 15840.00\end{array}$

SALES REPORT

DOLLARS

\begin{tabular}{|c|c|c|c|c|c|c|c|c|c|}
\hline 1982 & 1983 & 1984 & 1985 & 1986 & 1987 & 1988 & 1989 & 1990 & 1991 \\
\hline $\begin{array}{l}0 . \\
0 .\end{array}$ & $\begin{array}{l}621562 . \\
621562 .\end{array}$ & $\begin{array}{l}621562 . \\
621562 .\end{array}$ & $\begin{array}{l}621562 . \\
621562 .\end{array}$ & $\begin{array}{l}621562 . \\
621562 .\end{array}$ & $\begin{array}{l}621562 . \\
621562 .\end{array}$ & $\begin{array}{l}621562 . \\
621562 .\end{array}$ & $\begin{array}{l}621562 . \\
621562 .\end{array}$ & $\begin{array}{l}621562 . \\
621562 .\end{array}$ & $\begin{array}{l}621562 . \\
621562 .\end{array}$ \\
\hline
\end{tabular}


TEXTILE FOAM DYEING OF CARPETS, BECK DYEING AS A BASE

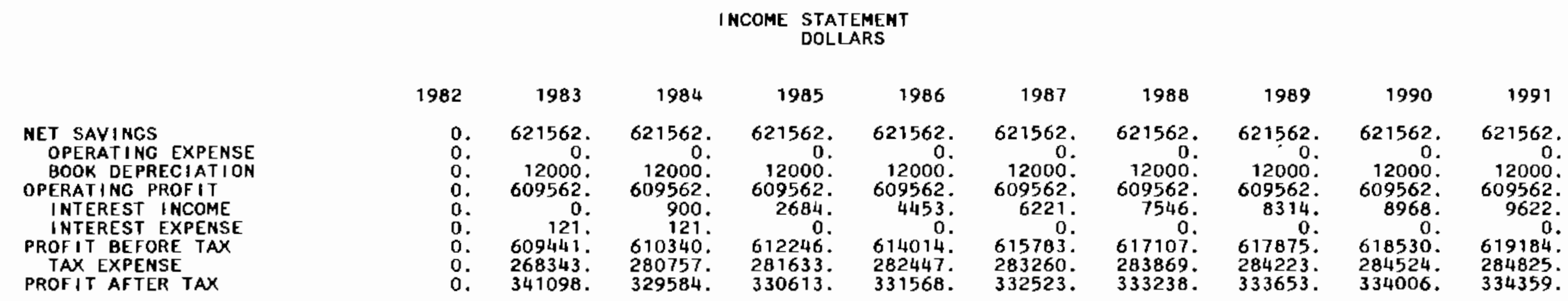

\section{$\stackrel{?}{\oplus}$}

FOR TAX PURPOSE

DEPRECIATION

TAXABLE I NCOME

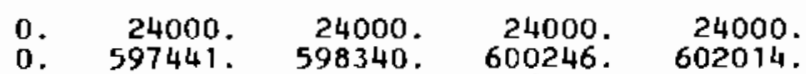

INCOME TAXES

D. 262823. 275237. 276113.

602014.

603783 .

603783 .

0.
629107
289389

629875: $\quad 630530$.

184

I NVESTMENT CREDIT USED

o. 12000 .

0 .

0 .

0.

0 .

0 .

0 .

0.

0 .

RETURN ON GROSS ASSETS
RETURN ON NET WORTH

RETURN ON NET OPERAT. ASSETS $\begin{array}{lll}0.0 & 173.5 & 116.8 \\ 0.0 & 212.4 & 163.8\end{array}$

$\begin{array}{lll}0.0 & 212.4 & 163.8 \\ 0.0 & 179.0 & 129.0\end{array}$

\section{2}

164.3
135.3

104.3

164.8

99.1
165.3

165.3
150.1

95.6
165.7

158.8

93.6
165.9

165.9
168.6

92.0
166.0

166.0
179.6

90.5
166.2

PAT = PROF IT AFTER TAX INTEREST EXPENSE) / AVERAGE BALANCE OF CURRENT ASSETS AND GROSS PLANT + EQUIPMENT

RONW = PAT / AVERAGE NET HORTH

RONA = PAT (ADJUSTED FOR INTEREST INCOME AND EXPENSE) / AVERAGE BALANCE OF NET FIXED ASSETS AND OPERATING WORKING CAPITAL (1.E.:CASH+RECE IVABLES+INVENTOR I ES+OTHER-PAYABLES)

**EQUITY PAYBACK PERIOD**

0.5 YEARS

AFTER END OF CONSTRUCTION 


\begin{tabular}{|c|c|c|c|c|c|c|c|c|c|c|}
\hline $\begin{array}{l}\text { \$\$\$\$ } \\
\$ \$ \$ \\
\$ \$ \$ \$ \\
\$\end{array}$ & $\begin{array}{l}\text { S\$\$ } \\
\$ \\
\$ \\
\$ \$ \$\end{array}$ & 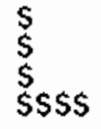 & FINANCIAL & $\begin{array}{l}\text { ANALYS!S } \\
=\quad \text { SEPT }\end{array}$ & $\stackrel{8}{1981}$ & $\begin{array}{l}\text { PRODUCT } \\
\text { VERSION }\end{array}$ & $P R I C I N G$ & MODEL & $\begin{array}{l}\text { \$\$\$\$ } \\
\mathbf{S} \$ \\
\$ \$ \$ \$ \\
\$ \$\end{array}$ & 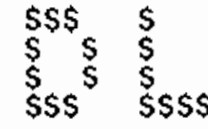 \\
\hline
\end{tabular}

TEXTILE FOAM DYEING OF CARPETS, BECK DYEING AS A BASE ENERGY

$$
\begin{aligned}
& \text { SALES VOLUME } \\
& \text { THOUSAND YARDS }
\end{aligned}
$$

$\begin{array}{rrrrrrrrrr}1982 & 1983 & 1984 & 1985 & 1986 & 1987 & 1988 & 1989 & 1990 & 1991 \\ & & & & & & & & \\ 0.0 & 15840.00 & 15840.00 & 15840.00 & 15840.00 & 15840.00 & 15840.00 & 15840.00 & 15840.00 & 15840.00 \\ 0.0 & 15840.00 & 15840.00 & 15840.00 & 15840.00 & 15840.00 & 15840.00 & 15840.00 & 15840.00 & 15840.00\end{array}$
?

CARPETS
TOTAL VOLUME

\section{CARPETS}

TOTAL SAVINGS

\section{SALES REPORT}

DOLLARS

\begin{tabular}{|c|c|c|c|c|c|c|c|c|c|}
\hline 1982 & 1983 & 1984 & 1985 & 1986 & 1987 & 1988 & 1989 & 1990 & 1991 \\
\hline $\begin{array}{l}0 . \\
0 .\end{array}$ & $\begin{array}{l}428313 . \\
428313 .\end{array}$ & $\begin{array}{l}428313 . \\
428313 .\end{array}$ & $\begin{array}{l}428313 . \\
428313 .\end{array}$ & $\begin{array}{l}428313 . \\
428313 .\end{array}$ & $\begin{array}{l}428313 . \\
428313 .\end{array}$ & $\begin{array}{l}428313 . \\
428313 .\end{array}$ & $\begin{array}{l}428313 . \\
428313 .\end{array}$ & $\begin{array}{l}428313 . \\
428313 .\end{array}$ & $\begin{array}{l}428313 \\
428313\end{array}$ \\
\hline
\end{tabular}


TEXTILE FOAM DYEING DF CARPETS, BECK DYEING AS A BASE ENERGY

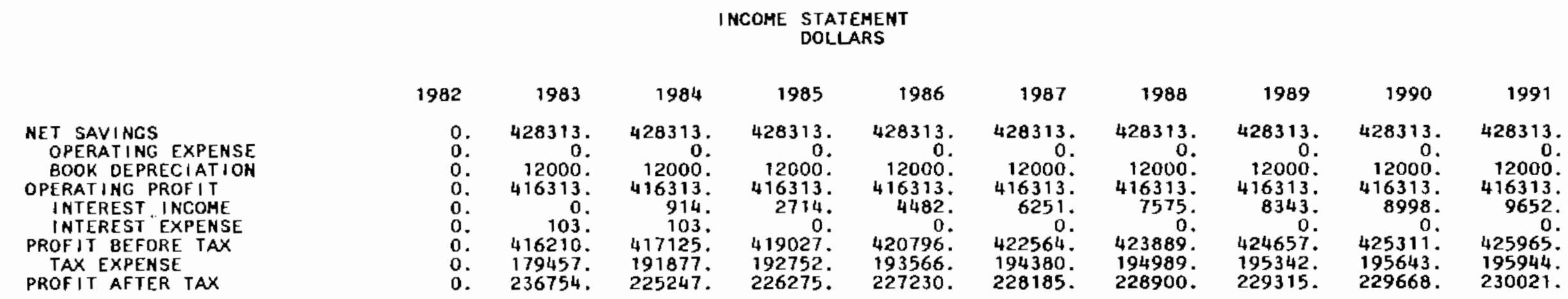

FOR TAX PURPOSE

DEPRECIATION

TAXABLE INCOME

INVESTMENT CREDIT USED

(BOOK AND TAX) $\begin{array}{rrrr}0 . & 24000 . & 24000 . & 24000 .\end{array}$

$\begin{array}{llll}0 . & 404210 . & 405125 . & 407027 . \\ 0 . & 173937 . & 186357 . & 187232 .\end{array}$

o. 12000 .

0.

0 ,
24000 . $\begin{array}{ll}408796 . & 410564 . \\ 188046 . & 188860 .\end{array}$

0.

0.
437965 . 201464.

0

RETURN ON GROSS ASSETS
RETURN ON NET WORTH

RETURN ON NET OPERAT. ASSETS

\section{$\begin{array}{ll}0.0 & 137.0 \\ 0.0 & 162.4\end{array}$}

$0.0 \quad 142.0$

96.0
131.3

89.5
131.9

84.0

108.3

114.9

132.4
122.4

79.2
133.0

76.0

74.2
133.6

72.8
133.8

133.8
165.8

71.4

PAT = PRDFIT AFTER TAX

ROGA = PAT (ADJUSTEO FOR INTEREST EXPENSE) / AVERAGE BALANCE OF CURRENT ASSETS AND CROSS PLANT + EQUIPMENT

RONW = PAT / AVERAGE NET WORTH

RONA = PAT (ADJUSTED FDR INTEREST INCOME AND EXPENSE) / AVERAGE BALANCE OF NET FIXED ASSETS AND OPERATING WORKING CAPITAL (1. E. : CASH+RECE IVABLES+ (NVENTDRI ES +OTHER-PAYABLES)

* EQUITY PAYBACK PERIOD * *

AFTER END OF CONSTRUCTION 


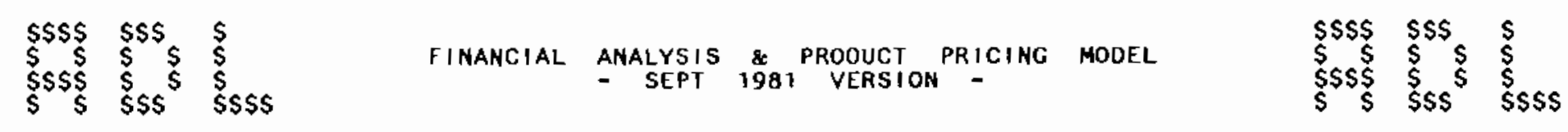

TEXTILE FOAM PROCESSING OF TUBULAR KNITS $5 \%$ INFLATION

\begin{tabular}{|c|c|c|c|c|c|c|c|c|c|}
\hline \multirow[b]{2}{*}{1982} & \multicolumn{4}{|c|}{$\begin{array}{l}\text { SALES VOLUME } \\
\text { THOUSAND YARDS }\end{array}$} & \multirow{2}{*}{1987} & \multirow[b]{2}{*}{1988} & \multirow[b]{2}{*}{1989} & \multirow{2}{*}{1990} & \multirow[b]{2}{*}{1991} \\
\hline & 1983 & 1984 & 1985 & 1986 & & & & & \\
\hline $\begin{array}{l}0.0 \\
0.0\end{array}$ & $\begin{array}{l}5300.00 \\
5300.00\end{array}$ & $\begin{array}{l}5300.00 \\
5300.00\end{array}$ & $\begin{array}{l}5300.00 \\
5300.00\end{array}$ & $\begin{array}{l}5300.00 \\
5300.00\end{array}$ & $\begin{array}{l}5300.00 \\
5300.00\end{array}$ & $\begin{array}{l}5300.00 \\
5300.00\end{array}$ & $\begin{array}{l}5300.00 \\
5300.00\end{array}$ & $\begin{array}{l}5300.00 \\
5300.00\end{array}$ & $\begin{array}{l}5300.00 \\
5300.00\end{array}$ \\
\hline
\end{tabular}

$\stackrel{?}{5}$

TUBULAR KNITS
TOTAL VOLUME

$5300.00 \quad 5300.00$

SALES REPORT

DOLLARS

1983

1984

1985

1986

1987

1988

1989

1990

1991

$\begin{array}{llllllllll}0 . & 140185 . & 147181 . & 354548 . & 162286 . & 170395 . & 178915 . & 187860 . & 197253 . & 207115 . \\ 0 . & 140185 . & 147181 . & 154548 . & 162286 . & 170395 . & 178915 . & 187860 . & 197253 . & 207115 .\end{array}$ 
TEXTILE FOAM PROCESSING OF TUBULAR KNITS $5 \%$ INFLATION

INCOME STATEMENT
DOLLARS

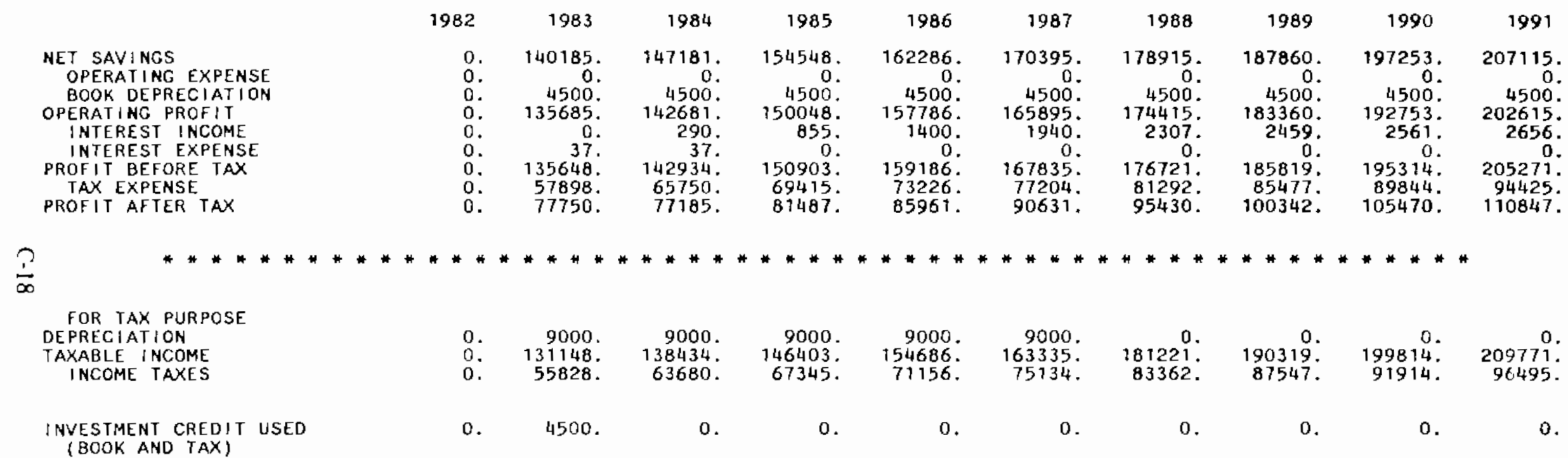

RETURN ON GROSS ASSETS

PEYURN OA HET HORTH

RETURN ON NET OPERAT. ASSETS

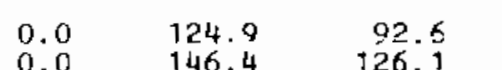

$\begin{array}{llll}0.0 & 124.9 & 92.6 & 82.8\end{array}$

$87.7 \quad 86.0$

86.0
148.0

85.9
155.9
148.8

87.4
163.9

162.4

89.3
772.3

177.2

PAT = PROFIT AFTER TAK

ROGA = PAT (ADJUSTED FOR INTEREST EXPENSE) / AVERAGE BALANCE OF CURRENT ASSETS AND GROSS PLANT + EQUIPMENT

RONW = PAT , AVERAGE NET WORTH

RONA = PAT (ADJUSTED FOR INTEREST INCOME AND EXPENSE) / AVERAGE BALANCE OF NET FIXED ASSETS AND OPERATING WORKING CAPITAL ( 1 . E. : CASH+RECEIVABLES+INVENTORIES+OTHER-PAYABLES) 


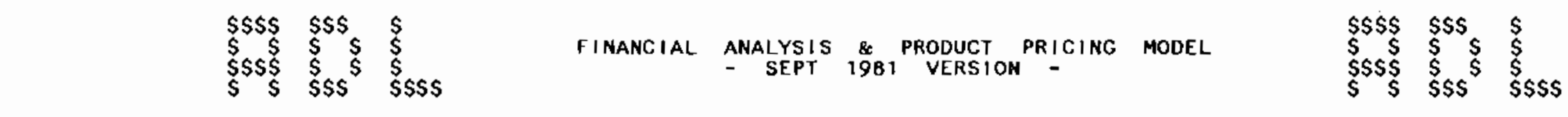

TEXTILE FOAM PROCESSING OF TUBULAR KNITS ENERGY ONLY 5\% INFL.

$$
\begin{aligned}
& \text { SALES VOLUME } \\
& \text { THOUSAND YARDS }
\end{aligned}
$$

\begin{tabular}{|c|c|c|c|c|c|c|c|c|c|c|}
\hline & 1982 & 1983 & 1984 & 1985 & 3986 & 1987 & 1988 & 1989 & 1990 & 1991 \\
\hline $\begin{array}{l}\text { TUBULAR KNITS } \\
\text { TOTAL VOLUME }\end{array}$ & $\begin{array}{l}0.0 \\
0.0\end{array}$ & $\begin{array}{l}5300.00 \\
5300.00\end{array}$ & $\begin{array}{l}5300.00 \\
5300.00\end{array}$ & $\begin{array}{l}5300.00 \\
5300.00\end{array}$ & $\begin{array}{l}5300.00 \\
5300.00\end{array}$ & $\begin{array}{l}5300.00 \\
5300.00\end{array}$ & $\begin{array}{l}5300.00 \\
5300.00\end{array}$ & $\begin{array}{l}5300.00 \\
5300.00\end{array}$ & $\begin{array}{l}5300.00 \\
5300.00\end{array}$ & $\begin{array}{l}5300.00 \\
5300.00\end{array}$ \\
\hline & \multicolumn{10}{|c|}{$\begin{array}{r}\text { SALES REPORT } \\
\text { DOLLARS }\end{array}$} \\
\hline & 1982 & 1983 & 1984 & 1985 & 1986 & 1987 & 1988 & 1989 & 1990 & 1991 \\
\hline $\begin{array}{l}\text { TUBULAR KNITS } \\
\text { TOTAL SAVINGS }\end{array}$ & $\begin{array}{l}0 . \\
0 .\end{array}$ & $\begin{array}{l}28673 . \\
28673 .\end{array}$ & $\begin{array}{l}30104 . \\
30104 .\end{array}$ & $\begin{array}{l}31588 . \\
31588 .\end{array}$ & $\begin{array}{l}33178 . \\
33178 .\end{array}$ & $\begin{array}{l}34874 \\
34874\end{array}$ & $\begin{array}{l}36618 . \\
36618\end{array}$ & $\begin{array}{l}38449 . \\
38449 .\end{array}$ & $\begin{array}{l}40371 . \\
40371\end{array}$ & $\begin{array}{l}42389 . \\
42389 .\end{array}$ \\
\hline
\end{tabular}


TEXTILE FOAM PROCESSING OF TUBULAR KNITS ENERGY ONLY $5 \%$ INFL.

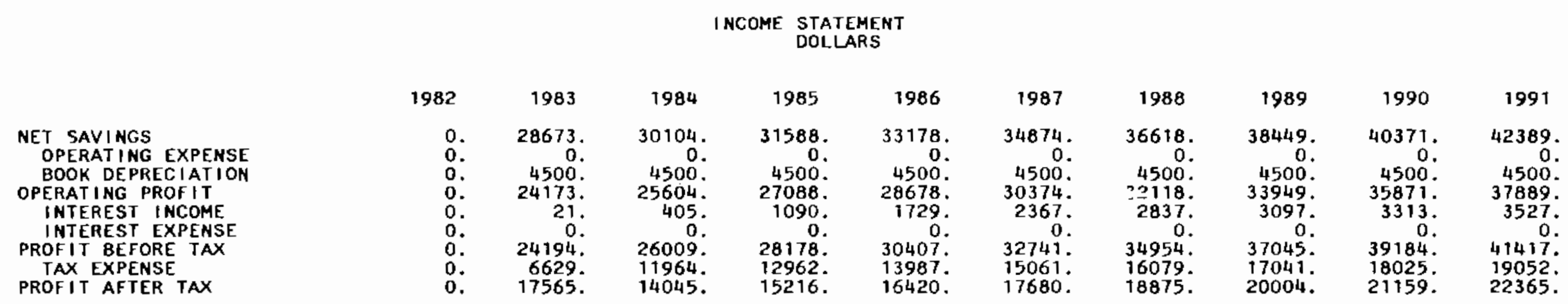

荢

FOR TAX PURPOSE

TAYABLE I NCOME

I NCOME TAXES

0. 9000 . 9000.

INVESTMENT CREDIT USED

(BOOK AMO TAX)

23678 . 9000.

9000 . 9000 .

$9000 . \quad 0$

0.

12991 .

18149.

41545.

19111 .

43684 .

20095 .

45917.

o. 4500 .

0

0.

0.

0.

0.

0.

0.

\section{***********}

RETURN ON GROSS ASSETS

RETURN ON NET HORTH
RETURN ON NET OPERAT. ASSETS

$\begin{array}{lllll}0.0 & 36.0 & 24.9 & 24.0 & 23.4 \\ 0.0 & 39.0 & 31.2 & 33.8 & 36.5 \\ 0.0 & 37.9 & 30.4 & 35.4 & 41.6\end{array}$

23.4
36.5

22.9

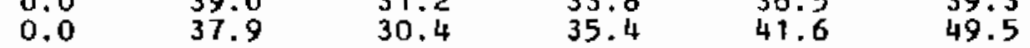

23.0

41.9
59.7

23.5
44.5

24.1

47.0

24.7

PAT = PROFIT AFTER TAX

PAT = PROF I T AFTER TAX
ROGA = PAT (ADJUSTED FOR INTEREST EXPENSE) / AVERAGE BALANCE OF CURRENT ASSETS AND GROSS PLANT + EQUIPMENT

RONH = PAT / AVERAGE NET WORTH

RONA = PAT (ADJUSTED FOR INTEREST INCONE AND EXPENSE) / AVERAGE BALANCE OF NET FIXED ASSETS ANO OPERATING HORKING CAPITAL (I.E.: CASH+RECE IVABLES+INVENTORI ES+OTHER-PAYABLES) 


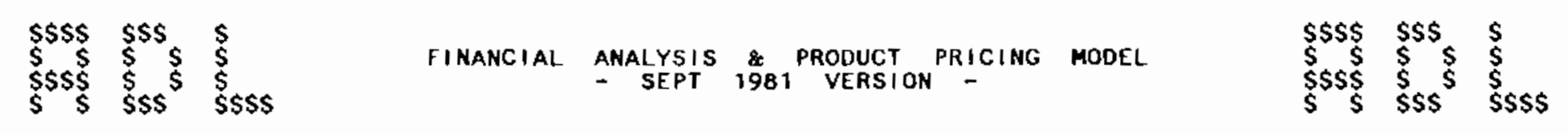

TEXTILE FOAM DYEING OF CARPETS, CONTINUOUS AS BASE CASE

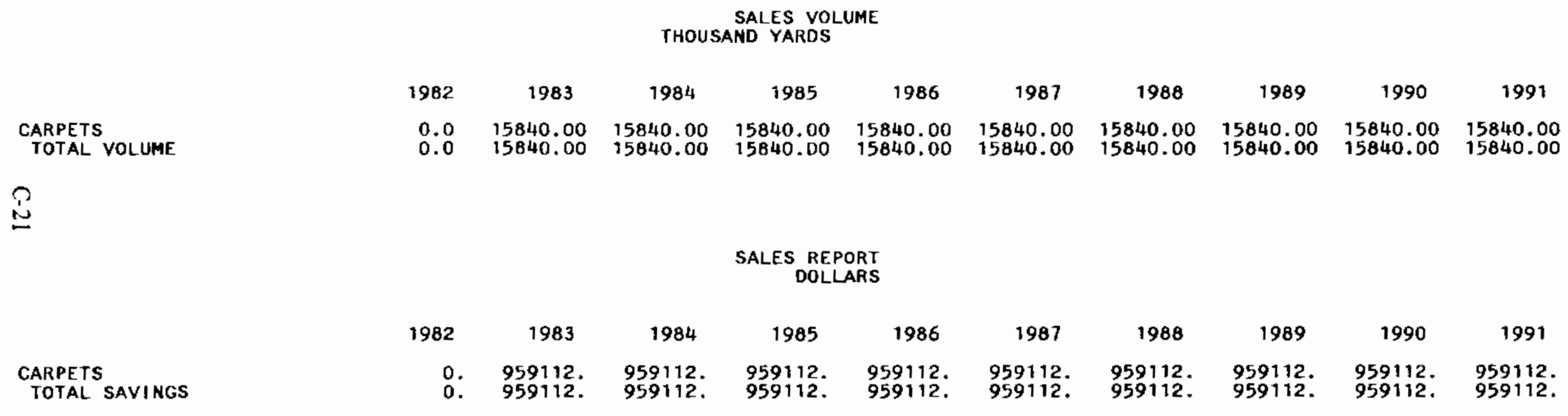


TEXTILE FOAM DYEING OF CARPETS, CONTINUOUS AS BASE CASE

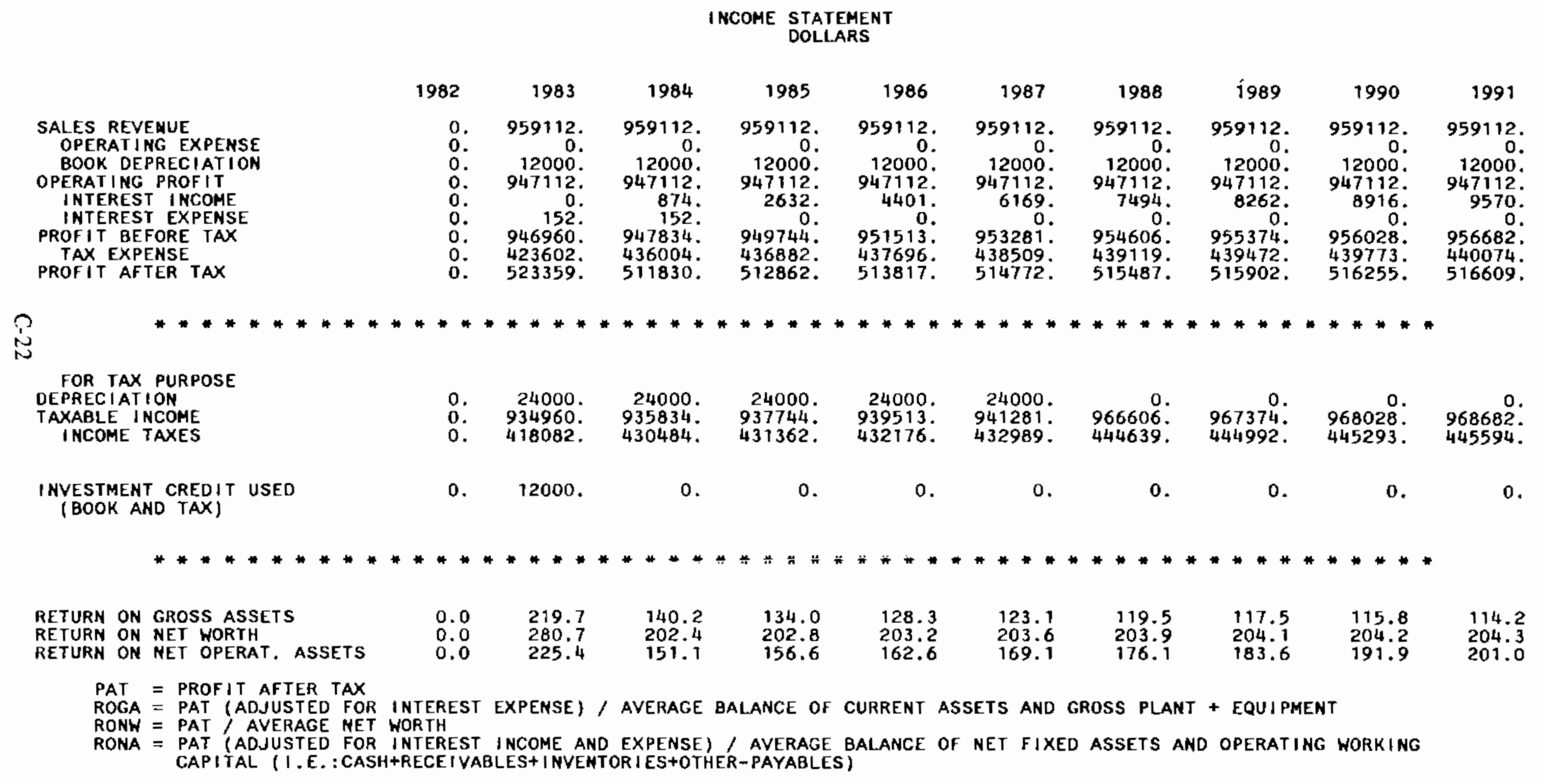

* EQUITY PAYBACK PERIOD** AFTER END OF CONSTRUCTION 


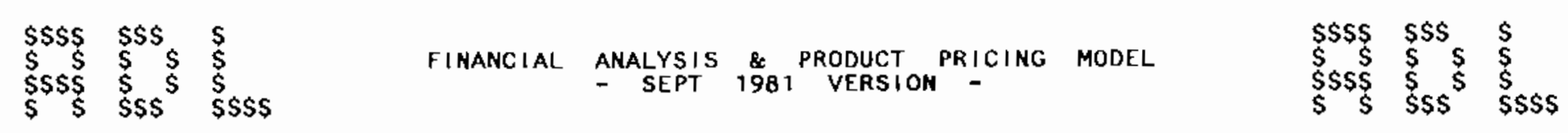

TEXTILE FOAM PROCESSING OF BROAD WOVENS $5 \%$ INFLATION

SALES VOLUME

THOUSAND YARDS

BROAD WOVENS
TOTAL VOLUME

ڤ

BROAD WOVENS

TOTAL SAVINGS

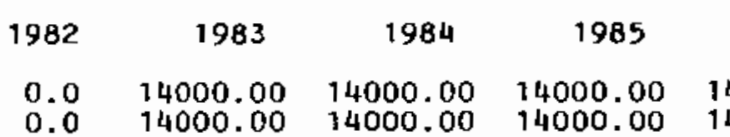

1986

1987

1988

1989

1990

1991

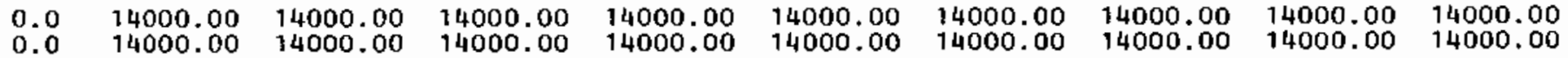

\section{SALES REPORT}

DOLLARS

\begin{tabular}{|c|c|c|c|c|c|c|c|c|c|}
\hline 1982 & 1983 & 1984 & 1985 & 1986 & 1987 & 1988 & 1989 & 1990 & 1991 \\
\hline $\begin{array}{l}0 . \\
0 .\end{array}$ & $\begin{array}{l}30800 \\
30800\end{array}$ & $\begin{array}{l}32340 . \\
32340\end{array}$ & $\begin{array}{l}34020 . \\
34020 .\end{array}$ & $\begin{array}{l}35700 . \\
35700 .\end{array}$ & $\begin{array}{l}37380 . \\
37380\end{array}$ & $\begin{array}{l}39249 . \\
39249 .\end{array}$ & $\begin{array}{l}41211 . \\
41211 .\end{array}$ & $\begin{array}{l}43272 . \\
43272 .\end{array}$ & $\begin{array}{l}45435 . \\
45435 .\end{array}$ \\
\hline
\end{tabular}


TEXTILE FOAM PROCESSING OF BROAD WOVENS 5\% INFLATION

I NCOME STATEMENT

DOLLARS

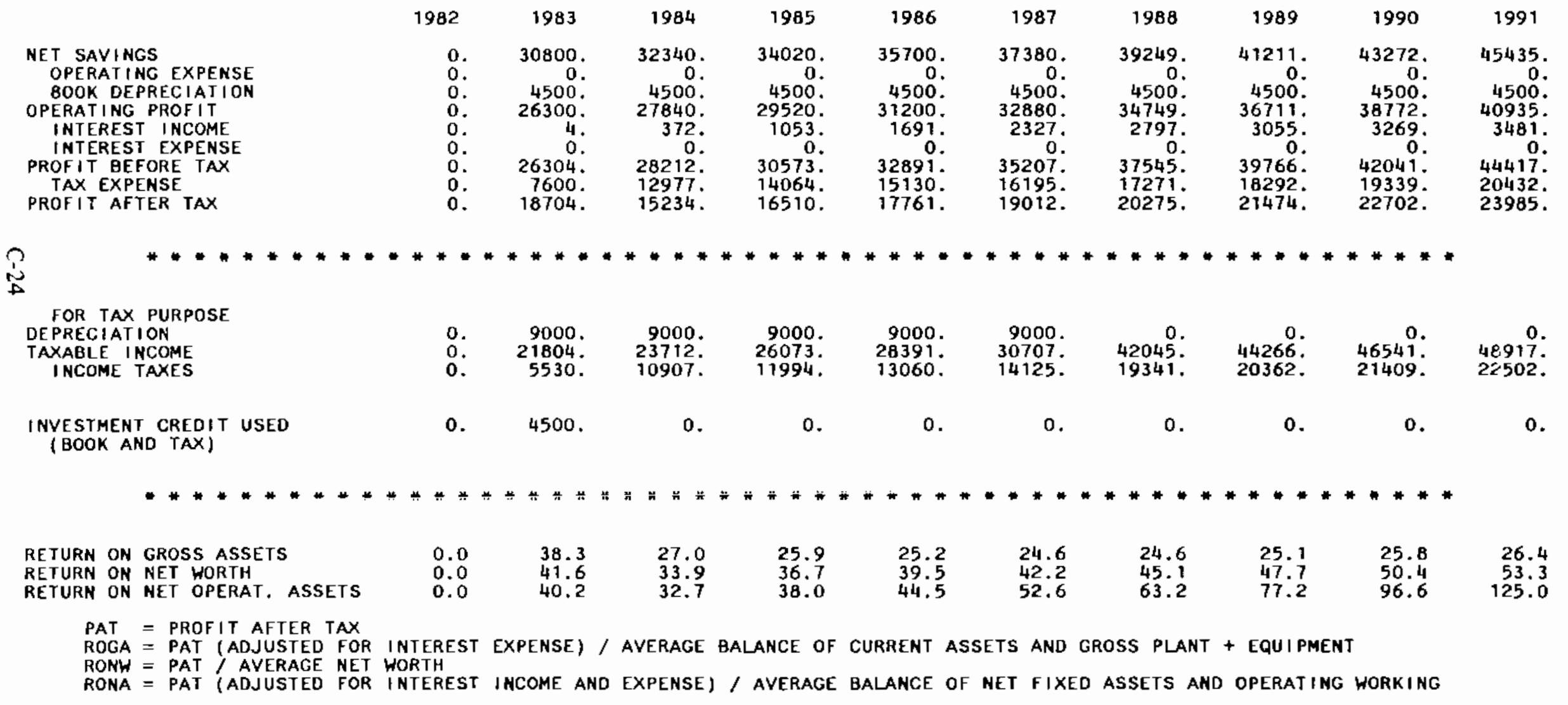




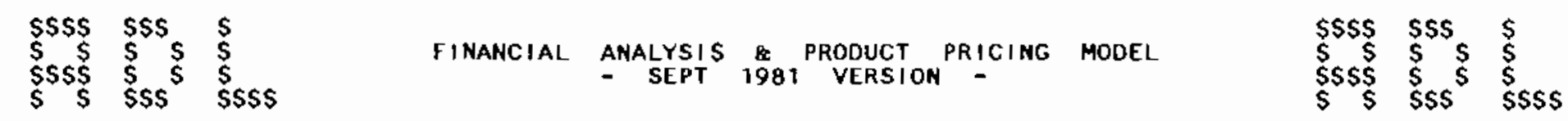

\section{TEXTILE FOAM PROCESSING OF BROAD WOVENS ENERGY ONLY $5 \%$ INFL.}

BROAD WOVENS

TOTAL VOLUME

心

BROAD WOVENS

TOTAL SAVINGS
SALES VOLUME

THOUSAND YARDS

$\begin{array}{rrrrrrrrrr}1982 & 1983 & 1984 & 1985 & 1986 & 1987 & 1988 & 1989 & 1990 & 1991 \\ 0.0 & 14000.00 & 14000.00 & 14000.00 & 14000.00 & 14000.00 & 14000.00 & 14000.00 & 14000.00 & 14000.00 \\ 0.0 & 14000.00 & 14000.00 & 14000.00 & 14000.00 & 14000.00 & 14000.00 & 14000.00 & 14000.00 & 14000.00\end{array}$

SALES REPORT

\begin{tabular}{|c|c|c|c|c|c|c|c|c|}
\hline 1982 & 1983 & 1984 & 1985 & 1986 & 1987 & 1988 & 1989 & 1990 \\
\hline 0. & $\begin{array}{c}10500 . \\
10500 .\end{array}$ & $\begin{array}{r}11060 . \\
11060 .\end{array}$ & $\begin{array}{r}11620 . \\
11620 .\end{array}$ & $\begin{array}{c}12180 . \\
12180 .\end{array}$ & $\begin{array}{r}12740 . \\
12740 .\end{array}$ & $\begin{array}{c}13377 \\
13377\end{array}$ & $\begin{array}{r}14046 \\
14046 .\end{array}$ & $\begin{array}{c}14748 . \\
14748 .\end{array}$ \\
\hline
\end{tabular}


TEXTILE FOAM PROCESSING OF BROAD WOVENS EMERGY ONLY $5 \%$ INFL.

I NCOME STATEMENT

\begin{tabular}{|c|c|c|c|c|c|c|c|c|c|c|}
\hline & 1982 & 1983 & 1984 & 1985 & 1986 & 1987 & 1988 & 1989 & 1990 & 1991 \\
\hline $\begin{array}{l}\text { NET SAYINGS } \\
\text { OPERAT ING EXPENSE } \\
\text { BOOK DEPRECIAT ION } \\
\text { OPERAT ING PROFIT } \\
\text { INTEREST INCOME } \\
\text { INTEREST EXPENSE } \\
\text { PROFIT BEFORE TAX } \\
\text { TAX EXPENSE } \\
\text { PROFIT AFTER TAX }\end{array}$ & $\begin{array}{l}0 . \\
0 . \\
0 . \\
0 . \\
0 . \\
0 . \\
0 . \\
0 . \\
0 .\end{array}$ & $\begin{array}{r}10500 \\
0 \\
4500 \\
6000 \\
200 \\
0 \\
6200 \\
2148 \\
4052\end{array}$ & $\begin{array}{r}11060 . \\
0 . \\
4500 \\
6560 \\
722 . \\
0 . \\
7282 . \\
2198 . \\
5084 .\end{array}$ & $\begin{array}{r}11620 . \\
0 . \\
4500 . \\
7120 . \\
1366 . \\
0 . \\
8486 . \\
2253 . \\
6233 .\end{array}$ & $\begin{array}{r}12180 . \\
0 . \\
4500 . \\
7680 . \\
2022 . \\
0 . \\
9702 . \\
3469 . \\
6233 .\end{array}$ & $\begin{array}{r}12740 . \\
0 . \\
4500 . \\
8240 . \\
2693 . \\
0 . \\
10933 . \\
5029 . \\
5904 .\end{array}$ & $\begin{array}{r}13377 . \\
0 . \\
4500 \\
8877 \\
3190 \\
0 . \\
12067 . \\
5551 . \\
6516 .\end{array}$ & $\begin{array}{r}14046 . \\
0 . \\
4500 \\
9546 . \\
3468 . \\
0 . \\
13014 . \\
5986 . \\
7028 .\end{array}$ & $\begin{array}{r}14748 . \\
0 . \\
4500 . \\
10248 . \\
3703 . \\
0 . \\
13951 . \\
6418 . \\
7534 .\end{array}$ & $\begin{array}{r}15485 . \\
0 . \\
4500 . \\
10985 . \\
3937 . \\
0 . \\
14923 . \\
6864 . \\
8058 .\end{array}$ \\
\hline
\end{tabular}

n

FOR TAX PURPOSE

DEPRECIATION

TAXABLE INCOME

0. 9000.9000 .9000 . 90.9000.

9000.

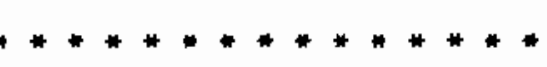

INVESTMENT CREDIT USED

(BOOK AND TAX)

$\begin{array}{rrrrr}0 . & 1700 . & 2782 . & 3986 . & 520 \\ 0 . & 78 . & 128 . & 183 . & 1399\end{array}$

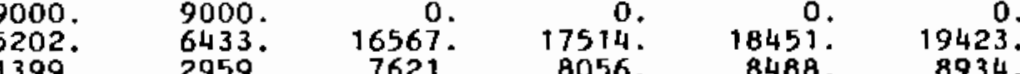

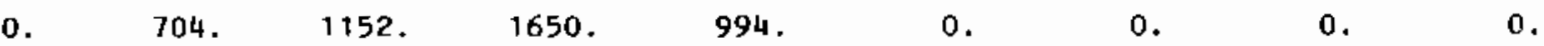

o.

RETURN ON GROSS ASSETS

RETURN ON NET HORTH

RETURN ON NET OPERAT. ASSETS

$0.0 \quad 8$.

8.4
9.0
8.9

$9 \cdot 3$
$11 \cdot 3$
$11 \cdot 2$

10.1
13.9

9.1
13.9

7.9
13.9

8.1

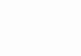

934.

PAT = PROFIT AFTER TAX

ROGA = PAT (ADJUSTED FOR INTEREST EXPENSE) / AVERAGE BALANCE OF CURRENT ASSETS AND GROSS PLANT + EQUIPMENT

RONH = PAT / AVERAGE NET WORTH
RONA = PAT (ADJUSTED FOR INTEREST INCOME AND EXPENSE) / AVERAGE BALANCE OF NET FIXED ASSETS AND OPERATING HORKING CAPITAL (1.E.: CASH+RECEIVABLES+INVENTORIES+OTHER-PAYABLES) 


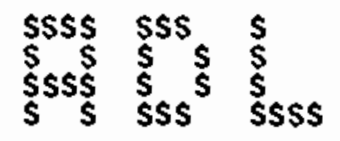

FINANCIAL ANALYSIS 8 PRODUCT PRICING MODEL

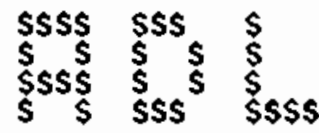

TEXTILE FOAM OYEING OF CARPETS, BECK DYEING AS A BASE $5 \%$ INFL.

\begin{tabular}{|c|c|c|c|c|c|c|c|c|c|}
\hline & & THous & $\begin{array}{l}\text { SALES VOI } \\
\text { AMD YAROS }\end{array}$ & & & & & & \\
\hline 982 & 1983 & 1984 & 1985 & 1986 & 1987 & 1988 & 1989 & 1990 & 1991 \\
\hline $\begin{array}{l}0.0 \\
0.0\end{array}$ & $\begin{array}{l}15840.00 \\
15840.00\end{array}$ & $\begin{array}{r}15840.00 \\
15640.00\end{array}$ & $\begin{array}{l}15840.00 \\
15840.00\end{array}$ & $\begin{array}{l}15840.00 \\
15840.00\end{array}$ & $\begin{array}{l}15840.00 \\
15840.00\end{array}$ & $\begin{array}{l}15840.00 \\
15840.00\end{array}$ & $\begin{array}{l}15840.00 \\
15840.00\end{array}$ & $\begin{array}{l}15840.00 \\
15840.00\end{array}$ & $\begin{array}{l}15840.00 \\
15840.00\end{array}$ \\
\hline
\end{tabular}

\section{CARPETS}

TOTAL VOLUME

in

CARPETS

TOTAL SAVINGS
$0.0 \quad 15840.00$ 15840.00
$15840.00 \quad 15840.00$

$15840.00 \quad 15840.00$

\section{SALES REPORT}

DOLLARS

$\begin{array}{llllllllll}1982 & 1983 & 1984 & 1985 & 1986 & 1987 & 1988 & 1989 & 1990 & 1991\end{array}$

0. 621562. 654350. 686981. 721353. 757469. 795342. 835108. 676863. 920705. 
TEXTILE FOAM DYEING OF CARPETS, BECK DYEING AS A BASE $5 \%$ INFL.

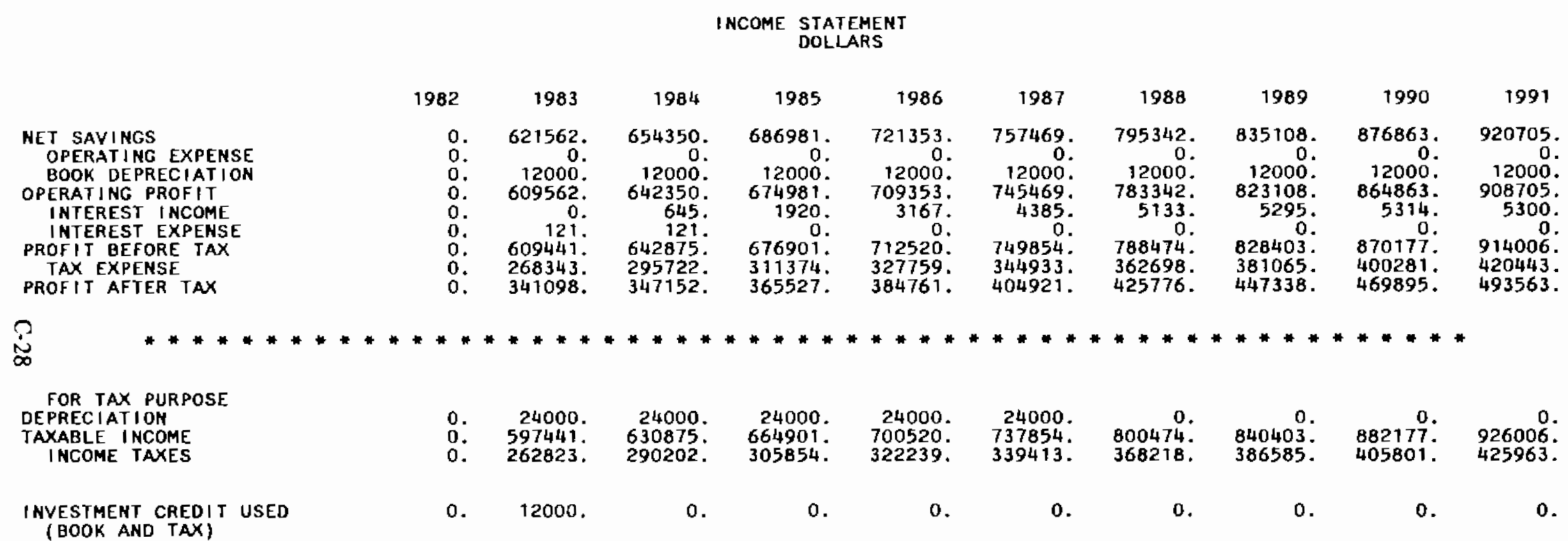

\section{RETURN ON GROSS ASSETS}

RETURN ON NET HORTH

RETURN ON NET OPERAT. ASSETS

122.3

PAT $=$ PROFIT AFTER TAX

ROGA = PAT (ADJUSTED FOR INTEREST EXPENSE) / AYERAGE BALANCE OF CURRENT ASSETS ANO GROSS PLANT + EQUIPMENT

RONH = PAT / AVERAGE NET HORTH

RONA = PAT (ADJUSTED FOR INTEREST INCOME AND EXPENSE) / AVERAGE BALANCE OF NET FIXED ASSETS AND OPERATING WORKING CAPITAL (I.E.: CASH+RECE IVABLES+INVENTORIES+OTHER-PAYABLES) 


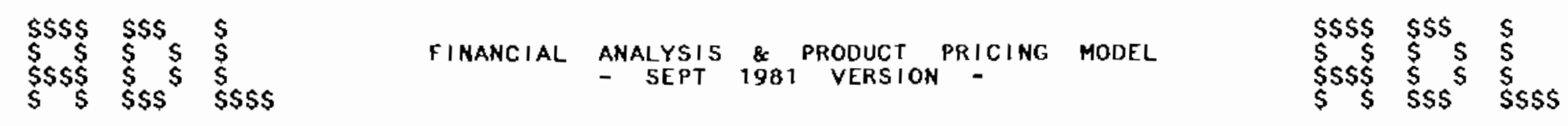

TEXTILE FOAM DYEING OF CARPETS, BECK DYEING AS A BASE ENERGY 5\% INF

\begin{tabular}{|c|c|c|c|c|c|c|c|c|c|}
\hline & & THOUS & $\begin{array}{l}\text { SALES VOL } \\
\text { AND YARDS }\end{array}$ & & & & & & \\
\hline 1982 & 1983 & 1984 & 1985 & 1986 & 1987 & 1988 & 1989 & 1990 & 1991 \\
\hline $\begin{array}{l}0.0 \\
0.0\end{array}$ & $\begin{array}{l}15840.00 \\
15840.00\end{array}$ & $\begin{array}{l}15840.00 \\
15840.00\end{array}$ & $\begin{array}{l}15840.00 \\
15840.00\end{array}$ & $\begin{array}{l}15840.00 \\
15840.00\end{array}$ & $\begin{array}{l}15840.00 \\
15840.00\end{array}$ & $\begin{array}{l}15840.00 \\
15840.00\end{array}$ & $\begin{array}{l}15840.00 \\
15840.00\end{array}$ & $\begin{array}{l}15840.00 \\
15840.00\end{array}$ & $\begin{array}{l}15840.00 \\
15840.00\end{array}$ \\
\hline
\end{tabular}

CARPETS
TOTAL VOLUME

?

CARPETS

TOTAL SAVINGS

\section{SALES REPORT
DOLLARS}

\begin{tabular}{|c|c|c|c|c|c|c|c|c|c|}
\hline 1982 & 1983 & 1984 & 1985 & 1986 & 1987 & 1988 & 1989 & 1990 & 1991 \\
\hline $\begin{array}{l}0 . \\
0 \text {, }\end{array}$ & $\begin{array}{l}428313 . \\
428313 .\end{array}$ & $\begin{array}{l}449698 . \\
449698 .\end{array}$ & $\begin{array}{l}472190 . \\
472190 .\end{array}$ & $\begin{array}{l}495792 . \\
495792 .\end{array}$ & $\begin{array}{l}520661 . \\
520661 .\end{array}$ & $\begin{array}{l}546693 . \\
546693 .\end{array}$ & $\begin{array}{l}574027 . \\
574027 .\end{array}$ & $\begin{array}{l}602728 . \\
602728 .\end{array}$ & $\begin{array}{l}632.864 \\
632864\end{array}$ \\
\hline
\end{tabular}


TEXTILE FOAM DYEING OF CARPETS, BECK DYEING AS A BASE ENERGY $5 \%$ INF INCOME STATEMENT

DOLLARS

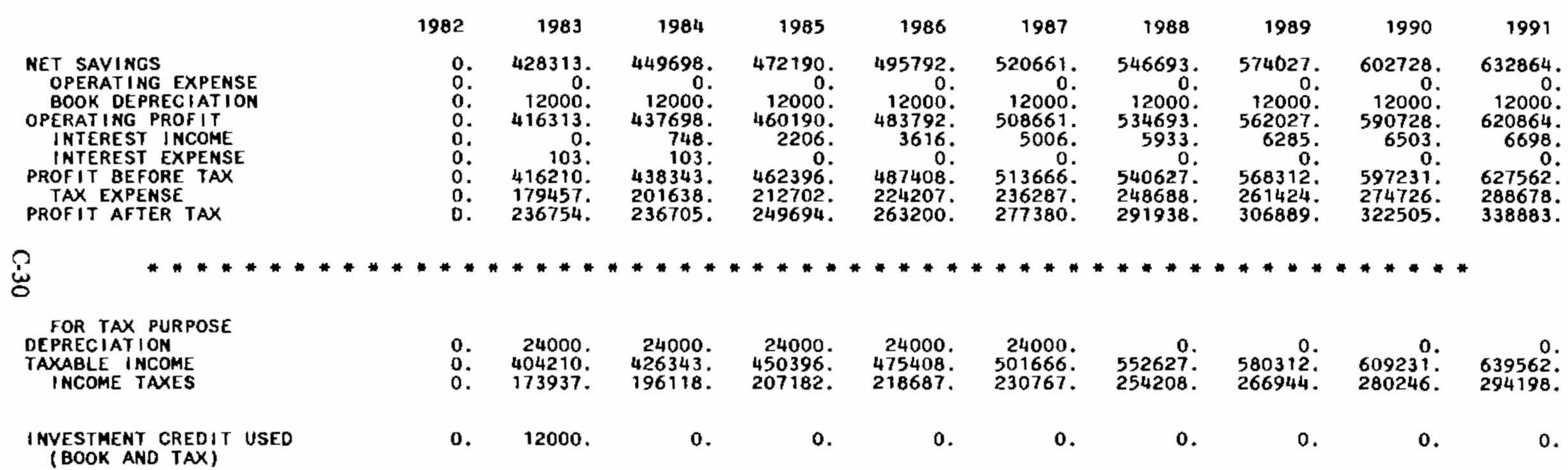
(BOOK AND TAX)

0. 12000 .

0.

0

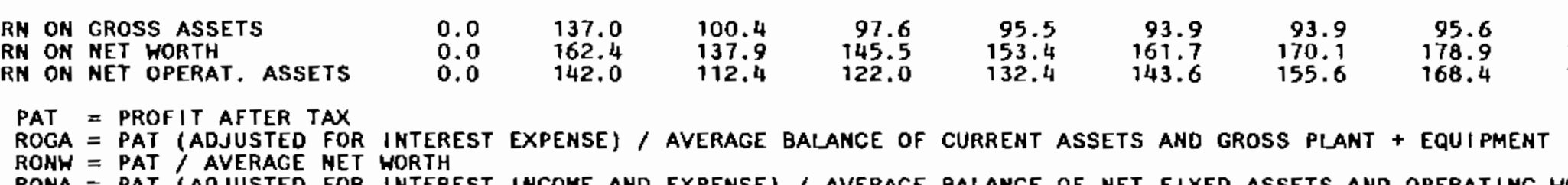

RETURN ON GROSS ASSETS
RETURN ON NET HORTH

RETURN ON NET HORTH
RETURN ON NEY OPERAT. ASSETS

PAT = PROFIT AFTER TAX

RONA = PAT (AOJUSTED FOR INTEREST INCOME AND EXPENSE) / AVERAGE BALANCE OF NET FIXED ASSETS AND OPERATING WORKING CAPITAL (I.E. : CASH+RECE IVABLES+I NVENTORIES+OTHER-PAYABLES)

* *EQUTY PAYBACK PERIO O** 0.7 YEARS
AFTER END OF CONSTRUCTION 


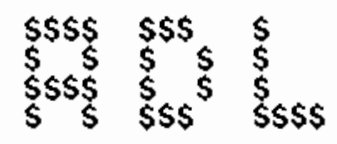

FIMANCIAL AMALYSIS - SEPT PRODUCT PRICING MODEL

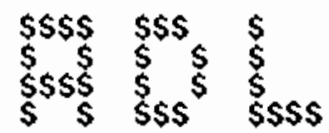

TEXTILE FOAM DYEING OF CARPETS, CONTINUOUS AS BASE CASE 5\% INF

CARPETS

TOTAL VOLUME

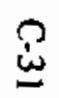

CARPETS

TOTAL SAVINGS

\section{SALES VOLUME
THOUSAND YARDS \\ SALES VOLUME
THOUSANO YARDS}

$\begin{array}{rrrrrrrrrr}1982 & 1983 & 1984 & 1985 & 1986 & 1987 & 1988 & 1989 & 1990 & 1991 \\ 0.0 & 15840.00 & 15840.00 & 15840.00 & 15840.00 & 15840.00 & 15840.00 & 15840.00 & 15840.00 & 15840.00 \\ 0.0 & 15840.00 & 15840.00 & 15840.00 & 15840.00 & 15840.00 & 15840.00 & 15840.00 & 15840.00 & 15840.00\end{array}$

SALES REPORT

DOLLARS

$\begin{array}{llllllllll}1982 & 1983 & 1984 & 1985 & 1986 & 1987 & 1988 & 1989 & 1990 & 1991\end{array}$

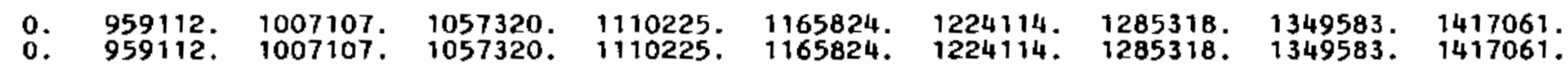


TEXTILE FOAM DYEING OF CARPETS, CONTINUOUS AS BASE CASE $5 \%$ INF

INCOME SIATEMENT

\begin{tabular}{|c|c|c|c|c|c|c|c|c|c|c|}
\hline & 1982 & 1983 & 1984 & 1985 & 1986 & 1987 & 1988 & 1989 & 1990 & 1991 \\
\hline $\begin{array}{l}\text { NET SAVINGS } \\
\text { OPERAT ING EXPENSE } \\
\text { BOOK DEPRECIATION } \\
\text { OPERAT ING PROFIT } \\
\text { INTEREST INCOME } \\
\text { INTEREST EXPENSE } \\
\text { PROFIT BEFORE TAX } \\
\text { TAX EXPENSE } \\
\text { PROFIT AFTER TAX }\end{array}$ & $\begin{array}{l}0 . \\
0 . \\
0 . \\
0 . \\
0 . \\
0 . \\
0 . \\
0 . \\
0 .\end{array}$ & $\begin{array}{r}959112 . \\
0 . \\
12000 . \\
947112 . \\
0 . \\
152 . \\
946960 . \\
423602 . \\
523359 .\end{array}$ & $\begin{array}{r}1007107 . \\
0 . \\
12000 . \\
995107 . \\
501 . \\
152 . \\
995456 . \\
457910 . \\
537547 .\end{array}$ & $\begin{array}{r}1057320 . \\
0 . \\
12000 . \\
1045320 . \\
1495 . \\
0 . \\
1046815 . \\
481535 . \\
565280 .\end{array}$ & $\begin{array}{r}1110225 . \\
0 . \\
12000 . \\
1098225 . \\
2460 . \\
0 . \\
1100684 . \\
506315 . \\
594369 .\end{array}$ & $\begin{array}{r}1165824 . \\
0 . \\
12000 . \\
1153824 . \\
3382 . \\
0 . \\
1157205 . \\
532314 . \\
624891 .\end{array}$ & $\begin{array}{r}1224114 . \\
0 . \\
12000 . \\
1212174 . \\
3818 . \\
0 . \\
1215932 . \\
559329 . \\
656603 .\end{array}$ & $\begin{array}{r}1285318 . \\
0 . \\
12000 . \\
1273318 . \\
3654 . \\
0 . \\
1276972 . \\
587407 . \\
689565 .\end{array}$ & $\begin{array}{r}1349583 . \\
0 . \\
12000 . \\
1337583 . \\
3330 . \\
0 . \\
1340913 . \\
616820 . \\
724093 .\end{array}$ & $\begin{array}{r}1417061 . \\
0 . \\
12000 . \\
1405061 . \\
2957 . \\
0 . \\
1408017 . \\
647688 . \\
760329 .\end{array}$ \\
\hline
\end{tabular}

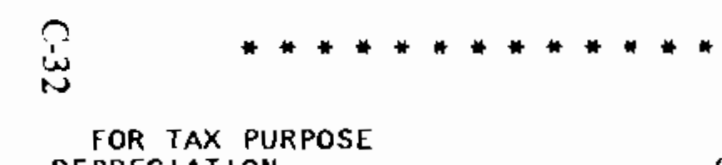

DEPRECIATI

TAXABLE INCOME

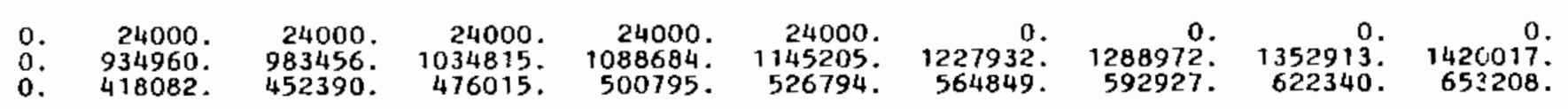

(NVESTMENT CREDIT USED
(BOOK AND TAX)

0. 12000 0. 0.0

o. 0 .

0 .

o. 0 .

0.

RETURN ON GROSS ASSETS

RETURA ON NET WORTH

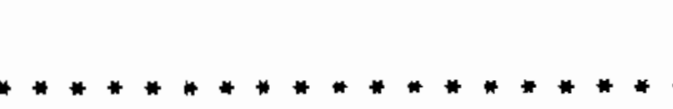

RETURN ON NET OPERAT. ASSETS

$\begin{array}{ll}0.0 & 219.7 \\ 0.0 & 280.7\end{array}$

346.3

145.1

144.3

$*$

*

PAT = PROFIT AFTER TAX

ROGA = PAT (ADJUSTED FOR INTEREST EXPENSE) / AVERAGE GALANCE OF CURRENT ASSETS ANO GROSS PLANT + EQUIPMENT

RONH = PAT / AVERAGE NET WORTH
RONA = PAT (ADJUSTED FOR INTEREST INCOME ANO EXPENSE) / AVERAGE BALANCE OF NET FIXED ASSETS AND OPERATING WORKING CAP ITAL (1.E.: CASH+RECE IVABLES+INVENTORIES+OTHER-PAYABLES) 


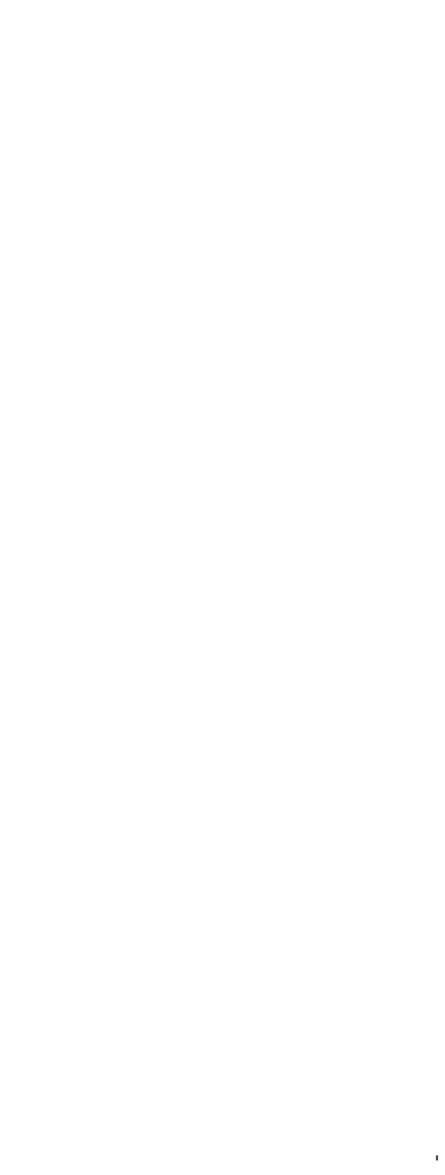

